Ding, S., Sun, P. and Jiang, W. (2016) The effect of import competition on firm productivity and innovation: does the distance to technology frontier matter? Oxford Bulletin of Economics and Statistics, 78(2), pp. 197-227. (doi:10.1111/obes.12110)

There may be differences between this version and the published version. You are advised to consult the publisher's version if you wish to cite from it.

This is the peer-reviewed version of the following article: Ding, S., Sun, P. and Jiang, W. (2016) The effect of import competition on firm productivity and innovation: does the distance to technology frontier matter? Oxford Bulletin of Economics and Statistics, 78(2), pp. 197227, which has been published in final form at 10.1111/obes.12110. This article may be used for non-commercial purposes in accordance with Wiley Terms and Conditions for Self-Archiving.

http://eprints.gla.ac.uk/107295/

Deposited on: 12 June 2015 


\title{
The effect of import competition on firm productivity and innovation: does the distance to technology frontier matter?*
}

\author{
Sai DING ${ }^{a}$, Puyang SUN ${ }^{b}$ and Wei JIANG ${ }^{c}$ \\ ${ }^{a}$ Department of Economics, Adam Smith Business School, University of Glasgow, Gilbert \\ Scott Building, Glasgow, UK, G12 8QQ . E-mail: sai.ding@glasgow.ac.uk . \\ ${ }^{b}$ Department of International Economics and Trade, Nankai University, Tianjin, P. R. China, \\ 300071. Email: puyangsun@nankai.edu.cn . \\ ${ }^{c}$ Department of International Economics and Trade, Nankai University, Tianjin, P. R. China, \\ 300071. Email: weijiang923@gmail.com .
}

\begin{abstract}
How does foreign competition affect growth and innovation in China? Using our unique measures of proximity of Chinese firms and industries to the world technology frontier, we find that despite vast sectoral heterogeneity, Chinese manufacturing industries have undergone rapid technological upgrading over the period of 2000-06. The distance to the world production frontier of firms and industries also play a significant role in shaping the nexus between the competition pressure from foreign imports and domestic firms' growth and innovation behavior. Our results support the theoretical predictions of Aghion et al. (2005) that import competition stimulates domestic firms' productivity growth and R\&D expenditure if firms and their industries are close to the world frontier, but discourages such incentives for laggard firms and industries. The two forces highlighted by the model operate for imports under the ordinary-trade regime, for collective and private firms, and for imports originated from high-income countries. Our findings are robust after controlling for the influence of foreign investment, the reverse causality of regressors and the short-term business cycle fluctuations.
\end{abstract}

\section{JEL Classification}

F14; L1; D24; O12

\section{Keywords}

Import competition; distance to frontier; productivity growth; innovation; China

\footnotetext{
* We are grateful for the extremely constructive comments from two anonymous referees and the journal editor, Professor John Knight.
} 


\section{Introduction}

International trade is widely viewed as a major driver for China's remarkable economic growth since the start of economic reform (see, Song et al., 2011; Knight and Ding, 2012). However, there is no consensus on whether the exposure to trade openness has stimulated the innovation incentives of domestic firms and therefore enhances their productivity. For instance, China has long been regarded as the world factory that produces cheap but inferior quality products whereas Chinese firms are considered as fast followers rather than leaders in terms of technology. This seems to be consistent with the predictions of the traditional Heckscher-Ohlin theory that countries that are abundant in labor ought to produce and export labor-intensive goods such as toys and apparel. On the other hand, both Rodrik (2006) and Schott (2008) find that China's export bundle is significantly more sophisticated than its income level would dictate, which cannot be entirely explained by factor endowments. There is also some recent evidence showing that China is moving up the technological curve in many sophisticated areas (such as the telecommunication equipment sector) and becoming a new innovation powerhouse with its share of the world's high-technology manufacturing spiraled from $8 \%$ in 2003 to $24 \%$ in 2012. Such striking trend corresponds well to the paradigm shift of national innovation policy towards indigenous innovation ${ }^{1}$ with more focus on domestic firms since 2005.

In this paper, we explore two interesting but related research questions. First, is there any technological upgrading of Chinese manufacturing firms and industries so that they are catching up the world technology frontier? Second, has the increased exposure to foreign competition through imports generated productivity gains and fostered innovation behavior within the Chinese manufacturing sector? The latter can be extended to a much broader research question: how does the import competition affect growth and innovation in China? The novelty and contribution of our research lie in the following four aspects.

First, despite a growing literature on China's trade pattern, most research focuses on the impact of exports on Chinese economy or the competition effect of Chinese imports to other developed and developing countries (see, Bloom et al., 2011; Jarreau and Poncet, 2012;

\footnotetext{
${ }^{1}$ The indigenous innovation is defined as 'enhancing original innovation through co-innovation and reinnovation based on the assimilation of imported technologies' in a State Council document titled by 'The outline plan of medium and long-term science and technology development 2006-2020'.
} 
Iacovone et al., 2013; Mion and Zhu, 2013; and Bloom et al., 2014) ${ }^{2}$. The important economic and policy implications of imports are thus largely ignored in the literature. For instance, imports may represent an important channel of international technology transfer, which can stimulate the development of industrial technology in related domestic industries through vertical linkage effects. We tend to fill this gap in the literature by focusing on the effect of competition pressure brought by imports on domestic firms' productivity and innovation behavior in China.

Second, we distinguish the heterogeneous effects of import competition on firms' productivity growth according to their distance to the world technology frontier. We hypothesize that tough foreign competition may induce the productivity improvement of domestic firms which are close to the technology frontier by strengthening their incentives to innovate in order to match the foreign competition; on the contrary, it may reduce firms' incentive to innovate and therefore their productivity growth if firms are further behind the frontier as their chance to survive the new competition is limited. To the best of our knowledge, we are the first in the literature to allow the relationship between import competition and productivity growth in China to depend on the proximity of the firm and industry to the world production frontier.

Third, we take into account a number of China-specific factors (such as the regional marketization status) when applying the distance-to-frontier model to explain the nexus between foreign competition and firm-level productivity growth. Moreover, we estimate the model for different ownership groups in order to explore whether some minimum institutional quality is required for the mechanisms of the model to operate as suggested by Acemoglu et al. (2006) and Amiti and Khandelwal (2013). Our results show that this is important given the presence of multi-dimensional sources of market frictions in China.

Fourth, we examine the trade-induced innovation hypothesis developed by Bloom et al. (2014) by distinguishing the origin of imports according to countries' income level. Our

\footnotetext{
${ }^{2}$ For instance, Jarreau and Poncet (2012) claim that export sophistication matters for China's growth and the growth gains from improved technology only link with domestic-owned firms and with ordinary trade. Iacovone et al. (2013) explore the effect of surge in import competition from China on Mexican manufacturing firms, and find that this shock causes a significant market share reallocation within firms and between firms. Mion and Zhu (2013) find evidence that import competition from China reduces firms' employment growth and induces substantial skill upgrading in low-tech manufacturing industries in Belgium. Bloom et al. (2014) develop a 'trapped factor' model to explain the effect of competition from low-wage imports (such as China) on European firms, i.e. rising Chinese import competition leads to more innovation and resource reallocation towards more innovative and technologically advanced firms in Europe, as found in Bloom et al. (2011).
} 
results indicate that there is a different mechanism working for China as the trapped factor model is originally developed for firms in advanced economies. To the best of our knowledge, we are the first to engage with this strand of literature when examining the impact of import competition in China.

Using a number of comprehensive micro-economic datasets, we find that despite vast sectoral heterogeneity, Chinese manufacturing industries have undergone rapid technological upgrading and converged quickly to the world production frontier over the period of 2000-06. Consistent with the theoretical predictions of Aghion et al. (2005), import competition spurs domestic firms' productivity growth and $R \& D$ expenditure if firms or their industries are close to the world frontier, but discourages such incentives for firms and industries which are far from the frontier. The two separation forces operate well for the ordinary-trade imports but not for the processing-trade imports. When estimating the model for various ownerships, both effects are evident for domestic collective and private firms, but not for the state sector or the foreign sector. We also find that import competition from high-income countries plays a major role in driving the productivity and innovation wedge among domestic firms and industries. Our findings remain intact when another source of foreign competition (i.e. foreign direct investment, FDI thereafter) is controlled for and when the business cycle effects are removed. We adopt both the two-stage instrumental variable (IV) approach and the system GMM estimator to deal with the potential endogeneity.

The structure of the paper is as follows. Section 2 briefly reviews the related theoretical and empirical literature. Section 3 addresses some background information on China's trade pattern and ownership reforms, with a focus on the role of imports. Section 4 explains our empirical model specification and hypotheses. Section 5 discusses the data and sample and presents some basic summary statistics. Section 6 interprets the results of our baseline model estimation and of various robustness checks. Section 7 concludes the paper.

2. Related literature: theory and evidence

\subsection{Theoretical background}

Our paper relates closely to at least two strands of interrelated literature in economic theory, i.e. the macroeconomic endogenous growth model and the industrial organization 
literature that analyzes product market competition and innovation. For instance, the endogenous growth model considers the process of learning and the adoption of new technologies as being costly; policies such as encouraging technological learning and technology imports may lead to higher growth rates. In particular, according to Schumpeter's appropriability argument (1943), the product-market competition is essential to the growth process, and competition reduces growth by reducing monopoly profits that reward innovation. Thus, the Schumpeterian theory predicts a linear and negative relationship between competition and innovation or economic growth.

This argument is challenged by Aghion et al. (2005) which claims that there is a nonmonotonic nexus between competition and innovation. Their theory is motivated by the evidence of a clear inverted-U relationship between competition and innovation using panel data, illustrated by Figure 1, which plots patents against the Lerner index. Their explanation for the inverted-U shape hinges critically on the incumbent's position relative to the world technology frontier, i.e. increasing competition stimulates innovative activity for firms at the technology frontier but reduces innovation if the firms are far from the frontier.

The basic intuition behind the distance-to-frontier model is as follows. The innovation incentives of incumbent firms are affected by the difference between their post-innovation and pre-innovation rents. On the one hand, for firms close to the technology frontier, competition can increase their incentives to innovate because it reduces firms' pre-innovation rents by more than it reduces their post-innovation rents. In other words, competition may increase the incremental profits from innovating for the incumbent leaders, and thereby encourage their R\&D investments aiming at escaping the threat of competition. This force is referred to as the 'escape-competition effect'. On the other hand, for firms far from the technology frontier, an increase in competition may reduce their incentives to innovate because ex post rents from innovation are eroded by new entrants, as in Schumpeter's appropriability argument. This is because in such sectors where innovations are made by laggard firms with already low initial profits, the product market competition will mainly affect the post-innovation rents. Thus, firms far from the frontier know that they cannot survive increased competition even if they successfully innovate. As a result, any policies that promote competition will discourage these laggard firms from spending resources on innovation. This leads to the 'discouragement effect'. In brief, the implications of the model are that the relationship between innovation and competition depends, in a non-monotonic 
way, on firms' distance to the world technology frontier as follows.

$$
\text { innovation }=f(\text { competition, } \text { distance to the frontier })
$$

Lastly, the theoretical literature on appropriate technology might also be relevant. Acemoglu (2002) advocates the idea of directed technological change and argues that technologies developed in industrialized countries may not be appropriate for developing countries whose factor endowments and socio-economic conditions are significantly different from those in developed economies. A similar idea in the trade literature is that although trade liberalization facilitates procurement of foreign technology, it is not clear whether domestic firms are able to adopt foreign technology. Eaton and Kortum (1996) argue that the impact of knowledge diffusion on productivity depends crucially on the proximity of a country to the technology source and the flexibility of the domestic labor force.

\subsection{Empirical evidence on the distance-to-frontier model}

The distance-to-frontier theory is well supported by both the macroeconomic and microeconomic empirical evidence. For instance, based on the cross-country data for the years 1974-1990, Acemoglu et al. (2006) distinguish the growth effect of innovation according to countries' distance to world technology frontier and find that innovation become more important as economies approach to the world technology frontier. They argue that barriers to competition should have limited costs when countries are far from the world technology frontier but should become much more costly near the frontier.

Using a rich panel of over 5,000 UK incumbent establishments in 180 4-digit industries over the period 1987-1993, Aghion et al. (2009) find evidence that the threat of technologically-advanced foreign entry spurs innovation incentives in sectors close to the technology frontier, where successful innovation allows incumbents to survive the threat, but discourages innovation in laggard sectors, where the threat reduces incumbents' expected rents from innovating. The causal effect proves to be robust when entry is instrumented by policy variables and when domestic entry and entry through imports are controlled for.

Amiti and Khandelwal (2013) analyze the effect of import competition on quality upgrading using highly disaggregated data on exports to the US from 56 countries in 10,000 products. They allow the relationship between tariffs and quality upgrading to depend on the 
proximity of the product to the world quality frontier and find strong evidence in support of the non-monotonic relationship, i.e. lower import tariffs promote quality upgrading of products that are initially close to the world technology frontier, but discourage quality upgrading of products that are distant from the world frontier.

\subsection{Empirical evidence on the effect of import competition on Chinese firms}

Our work connects closely to the recent empirical literature on the effect of trade liberalization, which suggests that trade can have a large positive impact on innovation and productivity $^{3}$. In comparison with the well-established cross-country evidence, the work on China is rather limited. One outstanding exception is $\mathrm{Yu}$ (2014) which examines the effect of tariff reduction on imported inputs and final goods on firm productivity. He considers the special tariff treatment that processing firms receive on imported inputs and constructs the firm-specific input and output tariffs. He finds that both types of tariff reductions have positive impacts on firm productivity, but the effect is weaker as firms' processing import share grows. However, none of the existing work takes into account firms' position relative to the world technology frontier when examining the trade liberalization effect in China, which leaves room for our study.

\section{China background}

\subsection{Trade liberalization and import competition in China}

China began trade liberalization with one of the most closed economies in the world, whose total trade over GDP ratio was marginally above 10 percent in 1978. With its open door policy, China's degree of integration into the world economy has improved dramatically. As shown in Figure 2, both exports and imports climbed strongly and persistently over the past three decades, and in 2013 China surpassed US as world's largest trading nation as measured by the sum of exports and imports. Regarding the role of imports, the country's import penetration ratio ${ }^{4}$ rose from $5 \%$ in 1978 to a peak of $31 \%$ in 2006 and stabilized around $24 \%$ afterwards. The high and rising aggregate import penetration ratio reflects the

\footnotetext{
${ }^{3}$ See for instance Pavcnik (2002) on Chile, Bernard et al. (2006) on the US, Amiti and Konings (2007) on Indonesia, Fernandes (2007) on Colombia, Aw et al. (2011) on Taiwan, Topalova and Kandelwal (2011) on India; and Bustos (2011) on Argentina.

${ }^{4}$ Import penetration ratio expresses imports as a percentage of domestic supply, which is GDP minus exports plus imports. It reflects the relative share of imports in the supply of goods available for domestic consumption.
} 
important but often-ignored role of imports in promoting competition and providing lowestcost supplies in the Chinese economy ${ }^{5}$.

Another feature of China's trade pattern is the sheer magnitude of processing trade ${ }^{6}$. According to $\mathrm{Yu}$ (2014), processing imports account for more than 50\% of China's total imports. However, it is interesting to see in Figure 3 that although the share of processing imports dominates that of ordinary imports in the 1990s, the importance of processing imports declines over time with a dramatic fall after 2005. In 2013, processing imports account for merely $25 \%$ of total imports in China whereas the corresponding figure for ordinary imports is $57 \%$. The fact that processing trade becomes less prevalent recently can be explained by a series of policy tightening on processing trade together with the rising labor costs in $\mathrm{China}^{7}$.

Lastly, Figure 4 shows that the majority of China's imports are from high-income countries $^{8}$, which accounts for on average $95 \%$ of total imports in China over the period of 1998-2013. The average import penetration ratio from high-income countries $(22.3 \%)$ is more than 17 times than that of low-income countries $(1.3 \%)$. There is some declining trend of high-income-country import share from $98 \%$ in 1998 to $93 \%$ in 2013 , which may reflect China's policy towards trade diversification by expanding its trade partners in developing and emerging markets ${ }^{9}$.

\subsection{Ownership reforms in China}

One distinguishing feature of China's institutional reform is the emergence of new

\footnotetext{
${ }^{5}$ The information on industry-level import penetration ratio is available in the Online Appendix 1.

${ }^{6}$ Processing trade is officially defined as business activities in which the operating enterprise imports all or part of the raw or ancillary materials, spare parts, components, and packaging materials, and re-exports finished products after processing or assembling these materials/parts (Manova and Yu, 2012).

${ }^{7}$ China has revised and tightened its policy on export tax rebate in 1994, 1996, 1997, 2002, 2003, and 2004 since its first introduction in 1985; in 2006, China started to restrict exports of high-energy-consumption, high pollution and resource-based products; and in 2007, China published a catalogue of products restricted from processing trade. All these policy shifts indicate the signal of tightening processing trade by Chinese government.

${ }^{8}$ The high- and low-income country classification is made by comparing the GDP per capita in 2000 (constant 2005 US\$, data from World Development Indicator) between China and other countries, i.e. countries with GDP per capita higher than China are referred to as high-income countries, and those with GDP per capita lower than China are referred to as low-income countries; the import penetration ratio is then computed for these two groups of countries. China's major importers include the European Union, US, South Korea, Canada, Australia, and Taiwai etc.

${ }^{9}$ For instance, China has been actively exploring trade opportunities in these markets through bilateral and free trade agreements (FTAs) with the Association of Southeast Asian Nations (ASEAN), Pakistan, India, Chile, Peru, and Costa Rica etc since 2002.
} 
forms of ownership. The Chinese industrial sector was initially dominated by state-owned enterprises (SOEs), whose directive was to fulfill production quotas, to transfer profits to government, and to provide life-long employment. Then collective and private firms began to grow rapidly in the 1980s and 1990s, who played a catalytic role in pushing China towards a market economy. Unlike SOEs, collective and private firms faced relatively hard budget constraints, so generating profit incentives. Deng Xiaoping's 'Southern Tour' in the spring of 1992 unleashed a surge of inward FDI to China, and foreign firms have been allowed steadily greater freedom to operate in the Chinese market. The Company Law adopted in 1994 provided a uniform legal framework into which all of the ownership forms fit, signaling the introduction of more clearly defined property rights and the start of the dramatic institutional change involved in the rapid downsizing of the state sector. Many SOEs and collective firms were shut down, privatized or turned into shareholding entities that are increasingly dominated by private owners. However, SOEs remain dominant in energy, natural resources and a few strategic or monopolistic sectors that are controlled and protected by central and local governments. Despite some evidence that the profitability of the state sector improved after 1998, SOEs are generally still less efficient than non-state firms (Ding et al., 2012).

Figure 5 illustrates the evolvement of China's imports by different ownership groups since $1995^{10}$. It is interesting to see that the majority of China's imports are carried out by foreign firms due to the massive FDI inflows to China, i.e. on average imports by foreign firms account for more than $53 \%$ of total imports in China. But the ratio began to shrink from its peak of $60 \%$ in 2006 to $45 \%$ in 2013 , corresponding to the recent policy shift away from processing trade. Over the entire sample period, imports by private firms climbed strongly and persistently from merely $3 \%$ in 1995 to $30 \%$ in 2013; on the contrary, the SOE imports declined dramatically from $50 \%$ in 1995 to $25 \%$ in 2013 . This contrasting trend reflects well the increasing role of private sector and the decreasing role of state sector in the Chinese economy.

Thus, our preliminary data observation shows that import competition is high and rising in China; processing imports are important but its role has declined over time; most imports to China are originated from high-income countries; and lastly, while foreign firms are the main importers, more and more domestic private firms are engaging with import

\footnotetext{
${ }^{10}$ The annual data is aggregated from the monthly report of China Customs Statistics, where only three types of ownerships (SOEs, private firms and foreign firms) are reported, i.e. there is no information for collective firms given its small and diminishing size in the economy.
} 
business in China.

\section{Our methodology}

\subsection{The hypotheses and our proxies for distance}

Following the discussion of the distance-to-frontier theory, we examine the heterogeneous effects of import competition on productivity improvement and innovation behavior of domestic firms. We hypothesize that foreign competition through imports does not necessarily increase the productivity of all domestic manufacturing firms in China, i.e. the relationship depends on the proximity to technology frontier of firms and industries due to the two forces discussed earlier. A caveat is in order: unlike firms in the advanced economies which hope to escape competition through innovation, the technology upgrading behavior of Chinese firms is mainly driven by a wish to stay in the game in the face of rising foreign competition. Therefore, the escape-competition effect may not be appropriate for China, and we would like to use the 'matching-competition effect' instead ${ }^{11}$.

In this paper, we are interested in examining the following two effects.

- The industry effect: increasing import competition has a more positive effect on firms' productivity growth in sectors that are close to the frontier than in sectors further behind the frontier.

- The firm effect: in each industrial sector, import penetration induces firms that are close to the technology frontier to innovate more and to improve productivity, but reduces such incentives if firms are distant from the frontier.

To test these hypotheses, we construct two alternative proxies for the distance to the technology frontier. First, the industry-distance-to-frontier (IDF) measure relates the labor productivity of 374 4-digit Chinese manufacturing industries to their US industry equivalents, where the US industries are used to represent the world technology frontier. Following Aghion et al. (2009), we compute the industry distance measure by using the 3-year moving average of US industry labor productivity relative to labor productivity in the respective Chinese industry as follows:

\footnotetext{
${ }^{11} \mathrm{We}$ thank one anonymous referee for raising this point.
} 


$$
I D F_{j p t}=\frac{L P_{j t}^{U S}}{L P_{j p t}}
$$

where $I D F_{j p t}$ is the distance of industry $j$ in province $p$ in China at time $t$ relative to its technology frontier; $L P_{j p t}$ is the labor productivity (defined as the value added per worker) of industry $j$ in province $p$ in China at time $t$; and $L P_{j t}^{U S}$ is the labor productivity of industry $j$ in the US. For each time period $t$, we average over the current and the two proceeding years in order to alleviate the business cycle effects and potential measurement errors ${ }^{12}$.

Similarly, the firm-distance-to-frontier (FDF) measure is defined as the 3-year moving average of US industry labor productivity relative to labor productivity of firms in the respective Chinese industry as follows:

$$
F D F_{i j t}=\frac{L P_{j t}^{U S}}{L P_{i j t}}
$$

where $F D F_{i j t}$ is the distance of firm $i$ in industry $j$ at time $t$ relative to its technology frontier; $L P_{i j t}$ is the labor productivity of firm $i$ in industry $j$ at time $t$; and $L P_{j t}^{U S}$ is the labor productivity of industry $j$ in the US. For both $I D F$ and $F D F$, the bigger the value of distance measure is, the further the Chinese industry or firm is away from the technology frontier in the US.

\subsection{Baseline model specification}

Our baseline model is specified as follows:

$$
Y_{i j t}=\alpha_{0}+\alpha_{1} I M P_{j t}+\alpha_{2} I M P_{j t} * D F_{j t}+\alpha_{3} D F_{j t}+\theta X_{i j t}+\eta_{t}+\xi_{i}+\zeta_{j}+\varsigma_{p}+\mu_{i j t}
$$

where the dependent variable $Y_{i j t}$ is a measure of growth or innovation performance of firm $i$ in industry $j$ at time $t$, which takes the form of either the TFP growth ${ }^{13}$ or the natural

\footnotetext{
${ }^{12}$ The distance variable is constructed based on the NBS data, which is available for the period of 1998-2007. Thus, we are able to compute the 3-year average for all the years of our merged dataset ranging from 2000-06.

${ }^{13}$ Our measure of firm-level TFP is constructed using the semi-parametric Olley and Pakes (1996) approach. See Online Appendix 2 for detailed methodology and results.
} 
logarithm of R\&D expenditure ${ }^{14}$.

$I M P_{j t}$ is the import penetration ratio in industry $j$ at time $t$, which is defined as follows:

$$
I M P_{j t}=\frac{\text { Import }_{j t}}{\text { Import }_{j t}+\text { Output }_{j t}-\text { Export }_{j t}}
$$

where Import $_{j t}$, Export $_{j t}$ and Output $t_{j t}$ are the total imports, exports and outputs of industry $j$ in time $t$. Compared with tariffs, import penetration ratio is argued to be a better proxy for trade liberalization, as it takes into account both tariff and non-tariff barriers of trade (Levinsohn, 1993).

$D F_{j t}$ is our distance proxy, which takes the form of either the industry distance measure $\left(I D F_{j p t}\right)$ or the firm distance measure $\left(F D F_{i j t}\right)$. We also include an interaction term between the import penetration ratio and the distance measure in equation (4). The distance-to-frontier model suggests that $\alpha_{1}>0$ and $\alpha_{2}<0$. Thus, a rise in the industry-level import penetration would spur firms' productivity growth or innovation behavior only if the firm or its industry is close to the world technology frontier; by contrast, if the firm or its industry is a long way from the frontier, a rising foreign competition through imported goods could reduce firms' innovation incentive and productivity growth. We keep an open view on the coefficient of $\alpha_{3}$, where $\alpha_{3}<0$ would indicate the presence of convergence effect, i.e. firms that are far from the technology frontier are catching up in terms of productivity growth and innovation behavior.

$X_{i j t}$ consists of three groups of control variables, i.e. the firm-specific factors, industryspecific factors, and China-specific factors. We include four firm-specific characteristics in equation (4), i.e. firm age, firm size, capital intensity and firm exit. Firm age $\left(a g e_{i t}\right)$ is defined as the difference between the current year $t$ and the opening year of the firm $i$. It is included to measure whether younger firms produce with greater efficiency or better technology than older ones (a vintage capital effect), or if through learning-by-doing productivity increases as the firm ages (see, for instance, Jensen et al., 2001). Firm size $\left(\operatorname{size}_{i t}\right)$ is the natural logarithm of total assets of firm $i$ in year $t$, which links with the characteristics of the production process in terms of returns to scale (either internal or

\footnotetext{
${ }^{14}$ The firm-level R\&D data is available in the NBS dataset (1998-2007) except for the years 1998,1999 and 2004.
} 
external to the firm). According to Haltiwanger (2011), static allocative efficiency implies that more productive firms are large or becoming larger and less productive firms are small or becoming smaller. However, empirical evidence shows that there are large differences in the within-industry covariance of size and productivity across countries (Bartelsman et al., 2013). Capital intensity (capital intensity ${ }_{i t}$ ), defined as the natural logarithm of capital stock over total employment of firm $i$ in year $t$, is another important component in the characterization of the production process, which reflects the combination of inputs in the production function. Lastly, we control for the exit of firms $\left(\right.$ exit $\left._{i t}\right)$ by including a dummy variable equal to one if firm $i$ exits in the following period. According to Pavcnik (2002), it is important to incorporate dynamics like firm exit in the productivity analysis in order to correct for the selection problem induced by existing firms. Similarly, using Indonesian data, Amiti and Konings (2007) find that firms that exit from the market are on average 4 percent less productive than those that remain in the market.

We construct the Herfindahl-Hirschman Index $\left(H H I_{j t}\right)$ as an industry-specific factor, aiming at capturing the market structure or the domestic competition status at the 4-digit industry level. A lower $H H I_{j t}$ indicates higher degree of competition in industry $j$. Syverson (2011) argues that competition drives productivity mainly through two key mechanisms. First, competition moves market share toward more efficient firms, i.e. inefficient firms are hard to survive in a very competitive market. The second mechanism acts through efficiency increases within firms, i.e. intensive competition can induce firms to take costly productivityenhancing actions that they may otherwise not. Thus, we hypothesize a negative and significant relationship between $H H I_{j t}$ and firms' productivity growth or R\&D expenditure in equation (4).

A number of China-specific factors are included in order to capture various sources of market frictions such as political economy factors that may affect the mechanisms of the model to operate. First, we include the ownership information of firms, which is based on the fraction of paid-in-capital contributed by the following six different types of investors: the state; foreign investors (excluding those from Hong Kong, Macao, and Taiwan); investors from Hong Kong, Macao, and Taiwan; legal entities; individuals; and collective investors ${ }^{15}$.

\footnotetext{
${ }^{15}$ Investors from Hong Kong, Macao, and Taiwan, and those from other parts of the world are entered separately because the former capture the so-called 'round-tripping' foreign direct investment, whereby domestic firms may register as foreign invested firms from nearby regions to take advantage of the benefits (such as tax and legal benefits) granted to foreign invested firms (Huang, 2003). Legal entities comprise
} 
We group all foreign firms (from Hong Kong, Macao, Taiwan, and other parts of the world) into a single foreign category; and all firms owned by legal entities and individuals into a single private category ${ }^{16}$. Thus our firms fall into four broad ownership groups - state-owned $(S O E)$, collective $(C O L)$, private $(P O E)$, and foreign $(F I E)$ - based on the shares of paid-incapital contributed by the four types of investors each year. We then group firms according to the majority average ownership shares. For instance, if the average share of capital paid-in by private investors over the sample period is greater than $50 \%$, then the firm is classified as privately owned. This approach is argued to be superior to the registration information of firms' ownership, as the latter does not reflect the dynamic nature of firm ownership evolution over the sample period.

Including the foreign ownership information is also crucial to (partly) control for another major channel of foreign competition and technology transfer, i.e. FDI. However, we find it challenging to completely disentangle the two sources of foreign competition, imports and FDI, in China due to the prevalence of processing trade. We therefore make an effort to control for the effect of FDI using firms' foreign share of capital ${ }^{17}$ when examining the role of import competition in driving firms' productivity and innovation behavior. More robustness tests are conducted to further distinguish the competition effect of imports from that of FDI in Section 6.

Second, market effectiveness is argued to have an important role in explaining differences on the allocative efficiency among Chinese provinces (Fan et al., 2007; Hsieh and Klenow, 2009). Our measure (market) is the natural logarithm of Fan et al. (2007)'s marketization index for different provinces in China, which captures government-market relationship, non-state sector development, product market development, factor market development, market intermediaries and the legal environment for the market. We expect that a more market-oriented environment helps to stimulate firms' productivity growth and

industrial enterprises, construction and real estate development companies, transportation and power companies, security companies, trust and investment companies, foundations and funds, banks, technology and research institutions etc. Collective firms are generally owned collectively by communities in urban or rural areas. The latter are known as township and village enterprises (TVEs).

${ }^{16}$ Within this category, firms owned by individuals make up about two thirds of the total. Firms owned by legal entities include firms owned by state legal entities. One could therefore question their inclusion in the private category. One reason for including them is that while the state's primary interest is political (i.e. aimed at maintaining employment levels or control over certain strategic industries), legal entities are profit-oriented (Wei et al., 2005). Since our dataset does not allow us to discriminate between state and non-state legal entities, we are unable to exclude the former from our private category. Our results were generally robust to excluding all firms owned by legal entities from the latter category.

${ }^{17}$ The foreign share definition is similar to that in Javorcik (2004). 
innovation behavior.

Lastly, the error term in equation (4) comprises five components: (i) the time-specific fixed effect, $\eta_{t}$, accounting for possible business cycles and macroeconomic shocks such as an appreciation of the Chinese yuan; (ii) the firm-specific fixed effect, $\xi_{i}$, controlling for any time-invariant unobserved firm specific features such as markups; (iii) the industry-specific fixed effect, $\zeta_{j}$, reflecting time-invariant industrial features affecting productivity such as factor costs and factor intensities; $(i v)$ the province-specific fixed effect, $\varsigma_{p}$, which captures geographic factors that influence productivity such as transportation costs, financial market development, tax treatment and so on; and $(v)$ an idiosyncratic error term, $\mu_{i j t}$, with normal distribution $\mu_{i j t} \bar{N}\left(0, \sigma_{i j}^{2}\right)$ to control for other unspecified factors. Our main estimation method is panel data fixed effect with standard errors clustered at the firm level. The twostage IV approach and system GMM estimator are adopted as alternative methods to address the potential endogeneity of regressors.

\section{Data and summary statistics}

\subsection{Data and sample}

Our research is based on a number of comprehensive microeconomic datasets, i.e. the firm-level production data drawn from the annual survey of Chinese industrial firms by National Bureau of Statistics (NBS), the transaction-level trade data from Chinese General Administration of Customs (GAC), the US industry-level production data from the NBER manufacturing productivity database, and the product-level tariff information published by World Trade Organization (WTO).

The first firm-level dataset is drawn from the annual accounting reports filed by industrial firms with the NBS over the period of 1998-2007. This dataset includes all SOEs and other types of enterprises with annual sales of five million yuan (about $\$ 817,000$ ) or more. These firms operate in the manufacturing sectors ${ }^{18}$ and are located in all 30 Chinese provinces or province-equivalent municipal cities ${ }^{19}$. Following the literature, we drop observations with negative total assets minus total fixed assets, negative total assets minus

\footnotetext{
${ }^{18}$ We exclude utilities and mining sectors for our research purpose in this paper.

${ }^{19}$ Our dataset does not contain any firm in Tibet.
} 
liquid assets, and negative sales, as well as negative accumulated depreciation minus current depreciation. Firms with less than eight employees are also excluded as they fall under a different legal regime (see, Brandt et al., 2012). Lastly, to isolate our results from potential outliers, we exclude observations in the one percent tails of each of the regression variables.

The second database from the Chinese Customs contains detailed transaction-level information of all imports and exports in China during the period of 2000-06, which includes 243 trading partners and 7526 different products in the 8-digit Harmonized System (HS). A feature of this dataset is its rich information on trade transactions. For instance, for each transaction it reports the transaction date, 8-digit HS product code, trade volume, trading partner, unit price, shipment method, trade regime and so on. To ensure the accuracy of the estimates, we eliminate the trading firms that do not engage in manufacturing but act as intermediaries between domestic producers/suppliers and foreign trade partners (see, Ahn et al., 2011; Manova and Zhang, 2012; and Yu, 2014) $)^{20}$.

The construction of our distance variables and their instruments requires the industrylevel production data from the US, which is obtained from the NBER manufacturing productivity database (June 2013 version). It contains the annual industry-level data for 459 4-digit industries over the period of 1958-2009. We manage to match the US industry code with the corresponding industry code in China, which gives us a sample of 374 4-digit industries in this paper. Lastly, in order to construct the instrument for the import penetration variable, we obtain the tariff data from WTO, which provides product-level tariffs at the 6digit HS level of all WTO member countries/regions. Following Yu (2014), we use the average ad valorem (AV) duty in our empirical regression ${ }^{21}$.

\subsection{Summary statistics}

We first present some summary statistics of our industry distance measure (IDF). Table 1 compares the distance value of top and bottom ten 4-digit industries in the year 2000 and 2006. It is interesting to find out that there is significant dynamics among the industries that are close to the world technology frontier over the sample period, i.e. only two light industries (manufacture of household air conditioner and manufacture of leather apparel) remain in the top-ten list of both 2000 and 2006. Moreover, the average distance in 2006 is

\footnotetext{
${ }^{20}$ See Online Appendix 3 for details of dataset merging techniques and outcomes.

${ }^{21}$ China's tariffs from 1998 to 2000 are missing from WTO, so we use the tariffs in 1997 for 2000 in our empirical analysis.
} 
merely half of that in 2000, indicating a further shrinkage of the industrial technology distance between China and US at the end of the sample period. The composition of these close-to-frontier industries changes too, i.e. in 2000, they mainly consist of some light industries (such as food processing, leather products etc.); whereas in 2006, some heavy industries (such as metal smelting and rolling processing, equipment and machinery manufacturing etc.) quickly catch up on the technology level relative to the world frontier. This shows some evidence of a more balanced industrial development pattern in China, i.e. both heavy and light industries have experienced technology improvement in recent years.

As for the industries that are far from the frontier, there are at least two trends which deserve a mention. First, compared with the world technology frontier, all the bottom ten industries have experienced significant technology improvement over the sample period, e.g. the maximum distance is 386.6 in 2000 , whereas the corresponding figure is reduced to 56.1 in 2006. Second, compared with other Chinese industries, many industries with low technology level in 2000 remain in the bottom-ten list in 2006 (e.g. industries of paper and paper products, petroleum processing and coking, and chemical material manufacturing etc.). Hence, despite the positive news that these laggard sectors have gradually converged to the world technology frontier over time, our data also reveals the sectors with persistent weak productivity or technology performance among Chinese industries which may require further policy attention.

At a more aggregate level, we find that the distance-to-frontier measure of most industries show a persistent declining trend over the entire sample period and the average annual growth rate is $-8.1 \%{ }^{22}$. Thus, by constructing our own distance-to-frontier measure, we are able to provide some basic answer to the question of whether there is any technological upgrading of Chinese manufacturing industries and whether they are catching up the world technology frontier. The answer is positive in general but with a great heterogeneity among various industries.

Table 2 presents the summary statistics of variables in the baseline model and the sample is split at the median value of the firm distance measure $(F D F)$. Generally speaking, firms which are close to the technology frontier have higher TFP growth and spend more on the R\&D activities; they are younger, larger and more capital intensive; they operate in a more competitive and market-oriented environment; and they are mainly non-state firms

\footnotetext{
${ }^{22}$ See Online Appendix 4 for more information on our distance-to-frontier measure at the 2-digit industry level.
} 
(collective, private and foreign firms). On the contrary, we find that firm's exit rate is higher among firms that are distant from the technology frontier, and they are mainly dominant by SOEs. From the summary statistics, the import penetration ratio does not show significant difference between the two subsamples. It is therefore interesting to explore whether firms' distance to the technology frontier plays a role in shaping the relationship between import competition and domestic firms' productivity improvement and innovation behavior when other firm-, industry-, and China-specific features are controlled for. This issue will be carefully investigated in the next session by using econometric analysis.

\section{Empirical results}

\subsection{Baseline model results}

Table 3 presents the baseline results of equation (4) where the dependent variable is the TFP growth. In all columns and for both distance-to-frontier measures (IDF and FDF), the import penetration ratio has a positive and significant positive effect on TFP growth, whereas the effect of an interaction term between the distance measure and import penetration appears to be significantly negative. This provides support for the effects highlighted in the theory of Aghion et al. (2005), i.e. the positive coefficient on the linear import variable implies that import competition tends to stimulate domestic firms' productivity growth if firms or their industries are close to the world frontier (the matching-competition effect); and the negative coefficient on the interaction implies that tougher competition from foreign imports is likely to discourage firms or industries distant from the frontier from productivity improvement as they are too far from the frontier to be able to compete with potential new entrants (the discouragement effect). The heterogeneous effects can be further illustrated through elasticity discussion. Taking column (1) as an example, the average net elasticity of firms' TFP growth with respect to import competition for industries that are far away from the frontier is -0.08 $(0.185-0.095 * 2.803)$, i.e. a 10 percentage point increase in import penetration is associated with a $0.8 \%$ fall in laggard firms' productivity growth. On the contrary, for industries close to the frontier, a rise in import competition has an opposite effect: a 10 percentage point increase in import penetration is associated with a $1.9 \%$ increase in firms' productivity growth. Rather than using the mean of the distance measure to compute the average elasticity, Berman et al. (2012) propose an alternative method to calculate the elasticity interval by using both the maximum and minimum value of the distance measure. Our corresponding elasticity range 
for industries distant from the frontier is from -0.38 to 0.09 in column (1). Similar results hold when province and industry fixed effects are included and when the firm distance measure $(F D F)$ is adopted ${ }^{23}$.

There is no robust evidence for the presence of convergence effect, i.e. the coefficient of the distance measure varies when $I D F$ and $F D F$ are adopted. The coefficients of all other control variables are consistent with theoretical predictions. In terms of the firm-specific variables, firm age is found to affect TFP growth significantly and negatively, which proves the vintage capital effect and rejects the hypothesis that productivity increases as the firm ages through learning-by-doing. The positive and significant correlation between firm size and productivity growth confirms the view of Haltiwanger (2011) that an important part of China's rapid growing productivity is due to the improvement of allocative efficiency. Productivity growth is found to be positively associated with firms' capital intensity, i.e. firms that are more capital intensive tend to have higher TFP growth. Lastly, in line with Pavcnik (2002) and Amiti and Konings (2007), we find that firms that dropped out from the market have lower productivity growth compared to those that did not.

The industry-specific $H H I$ has a negative effect on TFP growth, indicating that intensive competition in the domestic markets can stimulate firms to increase their efficiency and productivity. In terms of the China-specific variables, we include three ownership dummies (SOE, COL and FIE) in the estimation. Compared with the omitted default group, i.e. the private sector ( $P O E$ ), both state and collective firms have significantly lower productivity growth, whereas the productivity growth of foreign firms are not significantly different from that of private firms. This finding is consistent with the arguments that despite decades of economic reform, the state sector remains the least efficient group in the economy, with an average return on capital or productivity well below that in the private sector (Dougherty and Herd, 2005; Ding et al., 2012). By contrast, foreign firms, with certain cost advantages associated with specialized knowledge about production and better management or marketing capabilities, and domestic private firms are the most efficient and productive sectors in China. It is also interesting to see that the above separation effects of imports are evident after controlling for the presence of FDI. Lastly, we find that productivity growth is

\footnotetext{
${ }^{23}$ Despite the different magnitude of coefficients of key estimates (e.g. IMP and DF*IMP) when IDF and FDF are adopted, the elasticity or marginal effects are very similar. For instance, taking column (4) as an example, the average net elasticity of firms' TFP growth with respect to import competition for firms that are far away from the frontier is $-0.12\left(0.448-0.056^{*} 10.1\right)$, whereas the corresponding figure when industry distance measure is adopted is -0.08 . We thank one anonymous referee for raising this point.
} 
higher in the regions with higher level of market effectiveness.

The effect of import competition on firms' R\&D expenditure is reported in Appendix Table $\mathrm{A}(5)$ and we find very similar story to the case of productivity growth. In particular, the negative interaction effect counteracts the positive effect of import competition in firms and industries that are far away from the frontier. Thus, an increase in foreign competition reduces the laggard firms' incentives to innovate due to the discouragement effect. As firms approach the frontier, however, import competition can increase incentives to innovate due to the matching-competition effect.

In brief, our baseline results suggest that import competition drives a productivity and innovation wedge between firms that are close to and more distant to the technology frontier, consistent with the predictions of the distance-to-frontier model. All firm-, industry- and China-specific factors are important to be captured in order to facilitate the efficient operation of two separating forces.

\subsection{Robustness tests}

We conduct a number of robustness tests to address the heterogeneous effects of import competition in terms of different trade regimes, firm ownerships and origin of imports, to further distinguish the two sources of foreign competition (imports and FDI), to deal with the potential endogeneity of multiple regressors, and to focus on the long-run growth effects by removing the business cycles. To save space, we report the results on productivity growth only, and the corresponding results on firms' R\&D expenditure are very similar, which are available upon request.

\subsubsection{Processing versus ordinary-trade imports}

There is a rising literature on the effect of various trade regimes (ordinary versus processing trade) on firm performance in China, which indicates that generally speaking, firms conducting processing trade have inferior performance than their counterparts who are engaged in ordinary trade business (see, Jarreau and Poncet, 2012; Manova and Yu, 2012; Yu, 2014). For instance, Jarreau and Poncet (2012) claim that the growth-enhancing gains of trade are limited to the ordinary trade activities undertaken by domestic firms, but not processing trade activities. Yu (2014) find that the positive effect of reduction in input and 
output tariffs on firm productivity is weaker as firms' processing import share grows. Following this line of thinking, we distinguish the heterogeneous effects of imports in different trade regimes and expect that the two forces highlighted by the distance-to-frontier model may only work for imports under the ordinary trade regime.

Based on the information from the Customs dataset, we are able to classify all Chinese imports into two categories, i.e. processing-trade imports and ordinary-trade imports, which are then used to compute the processing-trade import penetration ratio (processing IMP) and ordinary-trade import penetration ratio (ordinary IMP). Their effects on productivity growth are presented in Table 4. In column (1), the positive coefficient on ordinary IMP and the negative coefficient on the interaction of ordinary IMP with the industry distance measure (IDF) provide support for the separation effects highlighted in Aghion et al. (2005). The average net elasticity of firms' TFP growth with respect to ordinary IMP for industries that are far away from the frontier is $-0.12(2.477-0.928 * 2.803)$, i.e. a 10 percentage point increase in import penetration under the ordinary-trade regime is associated with a $1.2 \%$ fall in laggard firms' productivity growth. The corresponding elasticity interval of such firms is from -3.1 to 1.5 . By contrast, for industries close to the frontier, a 10 percentage point increase in import penetration under ordinary-trade regime is associated with a $24.8 \%$ increase in firms' productivity growth. Similar results hold in column (4) when the firm distance measure $(F D F)$ is adopted.

Not surprisingly, in column (2), the effect of import penetration under the processingtrade regime (processing IMP) does not seem to support the hypothesis of the distance-tofrontier model and the result is further confirmed in column (3) when both types of import penetration are included in the same regression. There is also no consistent evidence when the firm distance measure $(F D F)$ is used, i.e. the model seems to work in column (5) but not in column (6) when both types of import penetration are simultaneously included in the estimation.

Thus, both the matching-competition effect and the discouragement effect highlighted by the model are strongly supported by the ordinary-trade imports but not the processingtrade imports. The larger marginal effect of ordinary-trade imports compared with the overall import penetration ratio in the baseline model also proves that it is the competition brought by ordinary-trade imports that makes the model work. Thus, only imports aiming for domestic markets are conductive to the productivity enhancement of firms and industries that 
are close to the frontier, but discouraging productivity improvement of laggard firms and industries. Those imports aiming for exporting after local processing have no such effect on domestic industries.

\subsubsection{Ownership heterogeneity}

It is argued that a minimum institutional quality is required for the mechanisms of the distance-to-frontier model to operate. For instance, Acemoglu et al. (2006) discuss how political economy can inhibit the escape-competition effect from operating in their theoretical model. Amiti and Khandelwal (2013) claim that the potential for entry and exit of firms is crucial for tariffs to invoke more competition in the home market. They also find empirical evidence that some countries with weak institutional quality or business environments display neither the discouragement nor the escape-competition forces.

Following this line of thinking, we distinguish the effect of import competition on productivity growth across four ownership groups and hypothesize that the model may only work for the non-state sectors in China. In Table 5, for both distance measures (IDF and $F D F$ ), the matching-competition effect for technologically advanced industries or firms and the discouragement effect for laggard industries or firms are only evident for collective firms and private firms, but not for SOEs and foreign firms. This indicates that the institutional obstacle in the state sector may hinder the two forces of the model to operate. In terms of foreign firms, the absence of such effects is not totally unexpected. On the one hand, as discussed in the background section, foreign firms play a dominant role in processing trade in China, and serve as an exporting platform for foreign countries ${ }^{24}$. Since foreign firms prefer to source inputs from aboard, the effect of foreign imports on their performance should be different from the competition pressure faced by the domestic firms. On the other hand, foreign-affiliates are less financially constrained due to their access to additional funding from their parent company (Manova et al., 2011). Such comparative advantages over local firms may also limit the competition pressure brought by foreign imports on their performance.

\subsubsection{Import competition from high- and low-income countries}

\footnotetext{
${ }^{24}$ During the period of 1996-2004, foreign firms accounts for $100 \%$ of exports out of the export processing zones, $95 \%$ of processing exports out of high-tech zones, and $67 \%$ of processing exports from the rest of China (Wang and Wei, 2010).
} 
Bloom et al. (2014) develop a general equilibrium model of trade with endogenous growth that allows factors of production to be temporarily 'trapped' in firms due to specific capital or moving costs. The theory predicts that in the face of an import shock from a lowwage country like China, firms in the affected industry may innovate more due to the fall of opportunity cost of innovation and a fall in the shadow cost of trapped factors. The "trapped factor' model thus provides an explanation for the phenomenon of trade-induced innovation in developed countries, i.e. firms respond to import competition from a low-wage country by developing an entirely new type of goods that will be less vulnerable to this type of competition. Using a panel of up to half a million firms over 1996-2007 across 12 European countries, Bloom et al. (2011) find evidence for the importance of low-wage-country imports for technical change in advanced economies.

It is therefore interesting to explore whether the trapped factor model (or part of it) is relevant in understanding the import competition effect in China. For this purpose, we classify the countries of origin of imports into two categories by comparing their income level with that of China in the beginning of our sample period. Countries with GDP per capita higher than China in 2000 are referred to as high-income countries, and those with income level lower than China are referred to as low-income countries ${ }^{25}$. We then compute the corresponding import penetration ratios for these two groups of countries, and refer them to High-income IMP and Low-income IMP respectively. We hypothesize that a different mechanism may work for China, as firms in developing countries usually operate with imperfect knowledge of technological alternatives and finding new technology is sometimes difficult and costly. Thus imports through access to capital goods and intermediate goods from technologically advanced countries may become a major form of technology transfer and a main source of competition that stimulates the competitiveness of domestic industry.

Table 6 presents the results. It is interesting to find that the separation effects of the distance-to-frontier model work only through the channel of imports from high-income countries, whereas the exposure to low-income countries does not have any sort of productivity-enhancement effects on Chinese firms. This is indeed opposite to the predictions of the trapped factor model for the reasons mentioned above. On the other hand, the distanceto-frontier theory works well for the imports from high-income countries. This is because imports from advanced countries are usually characterized by a superior technology and only

\footnotetext{
${ }^{25}$ The GDP per capita data (constant 2005 US\$) is from World Development Indicator (2014 version).
} 
firms close to the technology frontier may engage in innovative efforts in order to match such foreign competition whereas the innovation incentives of laggard firms and industries are dampened. Moreover, openness to trade with advanced economies offers the opportunity to exploit higher quality and higher technology intermediates that allow firms to increase their efficiency and competitiveness. However only the most productive firms can reap these benefits given the high costs involved in the entry in foreign supply markets. Thus, importing technology from advanced countries is important for a developing country like China, as efficient use of such technology requires creating new skills and knowledge to master its tacit elements, which improves domestic productivity.

\subsubsection{Foreign competition from FDI}

Both imports and FDI are important channels of international technology transfer and foreign competition. Their contribution to technological progress in a host country can be achieved directly through better intermediate inputs and machineries or indirectly through knowledge spillover. There is a large literature on the productivity spillover effect of FDI on domestic firms in developing countries (see, for instance, Javorcik, 2004; Blalock and Gertler, 2007; and Lopez, 2008). In the case of China, Fu (2011) examines the impact of processing trade-FDI on domestic firms' export competitiveness and finds that FDI associated with the processing-trade regime has generated little technology transfer for the development of competitiveness for indigenous firms. Xu and Sheng (2012) find evidence of positive productivity spillovers from FDI, which is mainly operated through forward linkages where domestic Chinese firms purchase high-quality intermediate goods or equipment from foreign firms in the upstream sectors. Jefferson and Ouyang (2014) investigate the literature on FDI spillovers in China and explain the reasons for the extensive difference in empirical findings.

It is therefore important to partial out the foreign competition through FDI when analyzing the import competition effects in China. In addition to our efforts of using firms' foreign share of capital to proxy FDI in the baseline model, we adopt an alternative control for FDI in Table 7 by using the ratio of foreign investment to total assets as in Fu and Gong (2011). We find that FDI intensity significantly contributes to firms' productivity growth and the separation effects predicted by Aghion et al. (2005) still operate well for imports when FDI intensity is controlled for. 
Moreover, when examining the correlation between our two measures of FDI and the import penetration variables in Appendix Table A6, we find that FDI is significantly and positively correlated with processing-trade import penetration, but not with ordinary-trade import penetration in China. Since our results show that the distance-to-frontier model works only for imports under the ordinary-trade regime, we can rule out the possibility that FDI is the key driver of the separation effects analyzed in the paper.

\subsubsection{Endogeneity}

A number of variables are potentially endogenous in the productivity growth or firm innovation regression. First, import penetration may not be exogenously given, but affected by firm's productivity growth or innovation behavior. With better performance, some firms may have stronger incentive to expand their business and thus requiring more input from abroad and local markets. Second, the distance-to-frontier measure can be endogenous in firms' performance equation, and may capture other industry-specific influences. We first adopt an IV estimator to address these concerns. Two sets of instruments are used in our analysis. First, following Yu (2014), we use the one-year lag of product-level output tariffs obtained from WTO as instruments for the import penetration variable. This is inspired by the literature such as Trefler (2004) and Amiti and Konings (2007), where the initial period of tariffs are proved to be valid instruments for tariff levels. Second, following Aghion et al. (2009), the US industry-level wage and the industry-level capital labor ratio are employed as instruments to the distance variable. The results in Table 8 confirm the exogenous role of imports in driving the productivity wedge between firms that are close to and more distant to the technology frontier.

Secondly, we use the system GMM estimator (Blundell and Bond, 1998) to estimate equation (4). This is particularly useful when other firm-specific variables (such as firm size, capital intensity and firm's exiting behavior) and industry-specific factor (such as $H H I$ ) are potentially endogenous. The system GMM estimator can also take into account unobserved firm heterogeneity and the possible mismeasurement problems of regressors. In additional to the above external instruments, levels of all potentially endogenous regressors lagged three times are used as instruments in the first-differenced equations and first-differenced variables lagged twice are used as additional instruments in the level equations. The Hansen $J$ test of over-identifying restrictions is adopted to evaluate the overall validity of the set of instruments. In assessing whether our models are correctly specified and consistent, we are 
also checking for the presence of second-order autocorrelation in the differenced residuals in all estimation. The results are reported in Appendix Table A7. By allowing for endogeneity of regressors discussed above, our results confirm the predictions of the distance-to-frontier model that industry-level import competition spurs firms' productivity growth in technologically advanced industries and firms, but not in laggard industries and firms. There is no evidence of second order serial correlation in the first-differenced residuals, and the Hansen test does not reject the validity of instruments.

\subsubsection{Long-term growth effects}

The distance-to-frontier model originates from the endogenous growth literature and has been applied to the cross-country growth regressions by Acemoglu et al. (2006). Despite the nature of our micro-level study in a short panel, the ultimate research question is about the impact of foreign competition on growth and innovation in China. However, the use of annual data may introduce unwanted business cycle effects into the long-term growth analysis. In Appendix Table A8, we opt for the non-overlapping three-year intervals in order to alleviate such cyclical effects in the estimation. The heterogeneous effects of import competition on productivity growth between technologically advanced firms/industries and lagging firms/industries are once again confirmed by the data. Thus, our findings that both the matching-competition and discouragement forces play a role in shaping the relationship between import competition and Chinese firms' growth performance is not driven by the temporary factors associated with business cycles.

\section{Conclusion}

Importing new technologies is viewed as a significant source of productivity and economic growth for developing countries, i.e. through adoption and imitation of imported technologies, countries can take advantage of $\mathrm{R} \& \mathrm{D}$ abroad to improve the efficiency of domestic production. Inspired by such arguments, we investigate the substantial heterogeneity of firms' productivity and innovation reactions to import competition in China. We find that Chinese manufacturing sectors have undergone dramatic technological upgrading and started to converge to the world technology frontier. After controlling for a number of firm-, industry- and China-specific factors, we find that domestic firms that are initially close to the world technology frontier benefit the most from foreign competition 
through imports, whereas for laggard firms that are distant from the frontier, import competition appears to dampen their innovation incentive and productivity growth. This corresponds well to the theoretical prediction of Aghion et al. (2005) which suggests systemic variation of firms' innovation incentives with their distance to the technology frontier.

Our research adds a number of new evidence to the economics literature. For instance, both the matching-competition effect and discouragement effect hold for imports under the ordinary-trade regime, whereas processing-trade imports do not seem to be conducive to domestic productivity enhancement or innovation. Controlling for China-specific variables such as firm ownerships is crucial for the model to work, and import penetration seems to have effects on the competitive pressures faced by domestic non-state firms only. Trade openness with advanced economies plays a major role in stimulating Chinese firms' productivity and innovation through the adoption of superior foreign technology.

Our findings have important implications for the policy debate on trade liberalization, competition policy, privatization and reforms in other sectors in China. For instance, fear of the initial costs of labor displacement and firm bankruptcies often deters governments from exposing their domestic markets to foreign competition. Our study highlights the productivity gains of trade openness and suggests that policies aiming at decreasing or removing trade barriers alone may not be sufficient to foster productivity growth or innovation behavior of domestic firms, i.e. complementary labor and product market reforms are important to improve the resource allocation efficiency by reallocating more resources from less to more technologically developed sectors where firms respond more positively to import competition. A further extension of our study may focus on applying the distance-to-frontier model to the analysis of the competition effects of foreign investment or foreign entry on domestic industries in China.

\section{Reference}

Acemoglu, D. (2002). Directed technical change. Review of Economic Studies, 69, 781-810.

Acemoglu, D., Aghion, P., \& Zilibotti, F. (2006). Distance to frontier, selection, and economic growth. Journal of European Economic Association, 4(1), 37-74. 
Aghion, P., Bloom, N., Blundell, R., Griffith, R., \& Howitt, P. (2005). Competition and innovation: An inverted-U relationship. The Quarterly Journal of Economics, 701-728.

Aghion, P., Blundell, R., Griffith, R., Howitt, P., \& Prantl, S. (2009). The effects of entry on incumbent innovation and productivity. The Review of Economics and Statistics, 91(1), 2032.

Ahn, J., Khandelwal, A., \& Wei, S.-J. (2011). The role of intermediaries in facilitating trade. Journal of International Economics, 84(1), 73-85.

Amiti, M., \& Konings, J. (2007). Trade liberalization, intermediate inputs, and productivity: Evidence from Indonesia. American Economic Review, 97(5), 1611-1638.

Amiti, M., \& Khandelwal, A. K. (2013). Import competition and quality upgrading. The Review of Economics and Statistics, 95(2), 476-490.

Aw, B., Roberts, M., \& Xu, D. (2011). R\&D, exporting and productivity dynamics. American Economic Review, 101, 1312-1344.

Bartelsman, E., Haltiwanger, J., \& Scarpetta, S. (2013). Cross-country differences in productivity: The role of allocation and selection. The American Economic Review, 103(1), 305-334.

Bernard, A., Jensen, B., \& Schott, P. (2006). Survival of the best fit: exposure to low-wage countries and the (uneven) growth of US manufacturing establishments. Journal of International Economics, 68(1), 219-237.

Berman, N., Martin, P., \& Mayer, T. (2012). How do different exporters react to exchange rate changes? The Quarterly Journal of Economics, 127, 437-492.

Blalock, G., \& Getler, P. (2007). Welfare gains from foreign direct investment through technology transfer to local suppliers. Journal of International Economics, 74(2), 402-421.

Blundell, R. \& S. Bond. (1998). Initial conditions and moment restrictions in dynamic panel data models. Journal of Econometrics, 87, 115-143.

Bloom, N., Draca, M., \& Van Reenen, J. (2011). Trade induced technical change? The impact of Chinese imports on innovation, IT and productivity. NBER Working Paper No. 16717. 
Bloom, N., Romer, P. M., Terry, S. J., \& Van Reenen, J. (2014). Trapped factors and China's impact on global growth. CEP Discussion Paper No. 1261.

Bowsher, C. G. (2002). On testing over-identifying restrictions in dynamic panel data models, Economics Letters, 77, 211-220.

Brandt, L., Van Biesebroeck, J., \& Zhang, Y. (2012). Creative accounting or creative destruction? Firm-level productivity growth in Chinese manufacturing. Journal of Development Economics, 97, 339-351.

Bustos, P. (2011). Trade liberalization, exports and technology upgrading: evidence on the impact of MERCOSUR on Argentinean firms. American Economic Review, 101(1), 304-340.

China Statistical Yearbook (2007). China Statistical Bureau, Beijing, China.

Ding, S., Guariglia, A. \& Knight, J. (2012). Negative Investment in China: Financing Constraints and Restructuring versus Growth. Leverhulme Centre for Research on Globalization and Economic Policy, Research Paper 12/01.

Dougherty, S., \& Herd, R. (2005). Fast falling barriers and growing concentration: the emergence of a private economy in China. OECD Economics Department Working Paper No. 471.

Eaton, J., \& Kortum, S. (1996). Trade in ideas: productivity and patenting in the OECD. Journal of International Economics, 40, 251-278.

Fan, G., Wang, X. \& Zhu, H., (2007). NERI Index of Marketisation for China's Provinces: 2006 Report (in Chinese), Economic Science Press, Beijing.

Feenstra, R. C., Li, Z., \& Yu, M. (2013). Exports and credit constraints under incomplete information: theory and evidence from China. Review of Economics and Statistics, forthcoming.

$\mathrm{Fu}, \mathrm{X}$. (2011). Processing trade, FDI and the exports of indigenous firms: Firm-level evidence from technology-intensive industries in China. Oxford Bulletin of Economics and Statistics, 73(6), $792-817$.

$\mathrm{Fu}$, X., \& Gong, Y. (2011). Indigenous and foreign innovation efforts and drivers of 
technological upgrading: evidence from China. World Development, 39(7), 1213-1225.

Haltiwanger, J. (2011). Firm dynamics and productivity growth. EIB Papers, 16, 116-136.

Hsieh, C.-T., \& Klenow, P. J. (2009). Misallocation and manufacturing TFP in China and India. The Quarterly Journal of Economics, CXXIV(4), 1403-1447.

Huang, Y. (2003). Selling China: Foreign Direct Investment during the Reform Era. New York: Cambridge University Press.

Iacovone, L., Rauch, F., \& Winters, A. (2013). Trade as an engine of creative destruction: Mexican experience with Chinese competition. Journal of International Economics, 89, 379392.

Jarreau, J., \& Poncet, S. (2012). Export sophistication and economic growth: Evidence from China. Journal of Development Economics, 97, 281-292.

Javorcik, B. (2004). Does foreign direct investment increase the productivity of domestic firms? In search of spillovers through backward linkages. American Economic Review, 93(4), 605-627.

Jefferson, G. \& Ouyang, M. (2014) FDI spillovers in China: why do the research findings differ so much? Journal of Chinese Economic and Business Studies, 12(1), 1-27.

Jensen, J., McGuckin, R., \& Stiroh, K. (2001). The impact of vintage and survival on productivity: evidence from cohorts of US manufacturing plants. The Review of Economics and Statistics, 83, 323-332.

Knight, J., and Ding, S. (2012) China's Remarkable Economic Growth. Oxford University Press.

Levinsohn, J. (1993). Testing the imports-as-market-discipline hypothesis. Journal of International Economics, 35, 1-22.

Lopez, R. (2008). Foreign technology licensing, productivity, spillovers. World Development, 3(4), 560-574.

Manova, K., Wei, S.-J., \& Zhang, Z. (2011). Firm exports and multinational activity under credit constraints. University of Stanford, Mimeograph. 
Manova, K., \& Yu, Z. (2012). Firms and credit constraints along the value-added chain: processing trade in China. University of Stanford, Mimeograph.

Manova, K., \& Zhang, Z. (2012). Export prices across firms and destinations. Quarterly Journal of Economics, 127, 379-436.

Mion, G., \& Zhu, L. (2013). Import competition from and offshoring to China: A curse or blessing for firms? Journal of International Economics, 89, 202-215.

Olley, S., \& Pakes, A. (1996). The dynamics of productivity in the telecommunications equipment industry. Econometrica, 64(6), 1263-1297.

Pavcnik, N. (2002). Trade liberalization, exit and productivity improvements: Evidence from Chilean plants. Review of Economic Studies, 69(1), 245-276.

Rodrik, D. (2006). What's so special about China's exports? NBER Working Paper Series No. 11947.

Roodman, D. (2009). A note on the theme of too many instruments, Oxford Bulletin of Economics and Statistics, 71 (1), 135-158.

Schott, P. (2008). The relative sophistication of Chinese exports. Economic Policy, 5-49.

Schumpeter, J. (1943). Capitalism, Socialism and Democracy. London: Allen Unwin.

Song, Z., Storesletten, K., \& Zilibotti, F. (2011). Growing like China. American Economic Review, 101, 202-241.

Syverson, C. (2011). What determines productivity? Journal of Economic Literature, 49(2), 326-365.

Topalova, P., \& Klandelwal, A. (2011). Trade liberalization and firm productivity: the case of India. The Review of Economics and Statistics, 93(3), 995-1009.

Trefler, D. (2004). The long and short of the Canada-US free trade agreement. American Economic Review, 94(4), 870-895.

Van Biesebroeck, J. (2007). Robustness of productivity estimates. Journal of Industrial Economics, 55(3), 529-569. 
Wang, Z., \& Wei, S.-J. (2010). What accounts for rising sophistication of China's exports? In R. C. Feenstra, \& S.-J. Wei, China's growing role in world trade (pp. 63-104). University of Chicago Press.

Wei, Z., Xie, F., and Zhang, S. (2005). Ownership structure and firm value in China's privatized firms. Journal of Financial and Quantitative Analysis , 40, 87-108.

Xu, X., \& Sheng, Y. (2012). Productivity spillovers from foreign direct investment: firm-level evidence from China. World Development, 40(1), 62-74.

Yu, M. (2014). Processing trade, tariff reductions and firm productivity: Evidence from Chinese firms. Economic Journal, forthcoming. 
Table 1. Summary statistics: top and bottom rank of distance to frontier at the 4-digit industry level (2000 versus 2006)

\begin{tabular}{|c|c|c|c|c|c|c|c|c|}
\hline Top rank & Year & $\begin{array}{l}\text { Industry } \\
\text { code }\end{array}$ & Industry name & Distance & Year & $\begin{array}{l}\text { Industry } \\
\text { code }\end{array}$ & Industry name & Distance \\
\hline 1 & 2000 & 3951 & Manufacture of household refrigerating appliances & 4.92 & 2006 & 3322 & Smelting of silver & 2.83 \\
\hline 2 & 2000 & 4051 & Manufacture of vacuum electron device & 5.32 & 2006 & 3331 & Smelting of tungsten and molybdenum & 3.06 \\
\hline 3 & 2000 & 1362 & $\begin{array}{l}\text { Production, pickled processing of gefillte fish and } \\
\text { aquatic }\end{array}$ & 5.38 & 2006 & 3674 & $\begin{array}{l}\text { Manufacture of animal husbandry } \\
\text { machinery }\end{array}$ & 3.50 \\
\hline 4 & 2000 & 3952 & Manufacture of household air conditioner & 6.40 & 2006 & 1931 & Tanning of fur & 3.64 \\
\hline 5 & 2000 & 4071 & Manufacture of household video equipment & 7.31 & 2006 & 1922 & Manufacture of leather apparel & 3.94 \\
\hline 6 & 2000 & 4041 & Manufacture of computer machine & 7.59 & 2006 & 3230 & Rolling processing of steel & 3.96 \\
\hline 7 & 2000 & 2433 & Manufacture of electronic musical instruments & 7.75 & 2006 & 3352 & Rolling processing of precious metal & 4.26 \\
\hline 8 & 2000 & 1922 & Manufacture of leather apparel & 8.26 & 2006 & 3513 & $\begin{array}{l}\text { Manufacture of the steam turbine and } \\
\text { auxiliary machinery }\end{array}$ & 4.29 \\
\hline 9 & 2000 & 1363 & Manufacture of aquatic feed & 8.48 & 2006 & 1910 & Tanning of leather & 4.41 \\
\hline 10 & 2000 & 1361 & Aquatic Products Freezing & 8.74 & 2006 & 3952 & $\begin{array}{l}\text { Manufacture of household air } \\
\text { conditioner }\end{array}$ & 4.45 \\
\hline $\begin{array}{c}\text { Bottom } \\
\text { rank }\end{array}$ & Year & $\begin{array}{l}\text { Industry } \\
\text { code }\end{array}$ & Industry name & Distance & Year & $\begin{array}{l}\text { Industry } \\
\text { code }\end{array}$ & Industry name & Distance \\
\hline 1 & 2000 & 4124 & $\begin{array}{l}\text { Manufacture of agriculture, forestry, animal } \\
\text { husbandry and fishery special instruments }\end{array}$ & 386.61 & 2006 & 4151 & Manufacture of film machinery & 56.05 \\
\hline 2 & 2000 & 4151 & Manufacture of film machinery & 141.81 & 2006 & 2625 & $\begin{array}{l}\text { Manufacture of organic fertilizer and } \\
\text { microbial fertilizer }\end{array}$ & 53.94 \\
\hline 3 & 2000 & 3514 & Manufacture of turbines and auxiliary equipment & 117.38 & 2006 & 1523 & Manufacture of yellow rice wine & 49.76 \\
\hline 4 & 2000 & 2625 & $\begin{array}{l}\text { Manufacture of organic fertilizer and microbial } \\
\text { fertilizer }\end{array}$ & 107.31 & 2006 & 2512 & Production of synthetic crude oil & 48.53 \\
\hline 5 & 2000 & 2512 & Production of synthetic crude oil & 105.06 & 2006 & 2631 & Manufacture of chemical pesticide & 47.87 \\
\hline 6 & 2000 & 3111 & Manufacture of cement & 94.15 & 2006 & 2222 & Manufacture of hand-made paper & 47.00 \\
\hline 7 & 2000 & 3674 & Manufacture of animal husbandry machinery & 90.89 & 2006 & 2824 & Manufacture of polyvinyl alcohol fiber & 44.04 \\
\hline 8 & 2000 & 2631 & Manufacture of chemical pesticide & 86.74 & 2006 & 2750 & Manufacture of veterinary drug & 42.79 \\
\hline 9 & 2000 & 2222 & Manufacture of hand-made paper & 84.73 & 2006 & 4142 & Manufacture of glasses & 41.58 \\
\hline 10 & 2000 & 2622 & Manufacture of phosphate fertilizer & 84.42 & 2006 & 3111 & Manufacture of cement & 39.00 \\
\hline
\end{tabular}

Notes: industry code is the 4-digit Chinese Standard Industrial Classification (CSIC) code. 
Table 2. Summary statistics: variables in the baseline model

\begin{tabular}{l|ccc|ccc}
\hline \multicolumn{1}{c|}{ Variables } & \multicolumn{3}{c}{ Close to frontier } & \multicolumn{3}{c}{ Far from frontier } \\
& Obs. & Mean & Std. Dev. & Obs. & Mean & Std. Dev. \\
\hline Dependent variables & & & & & & \\
TFP Growth & 477980 & 0.021 & 0.293 & 467402 & 0.020 & 0.276 \\
R\&D expenditure & 444563 & 0.644 & 1.917 & 444545 & 0.495 & 1.582 \\
Independent variables & & & & & & \\
Import penetration ratio (IMP) & 615191 & 0.017 & 0.054 & 615190 & 0.018 & 0.058 \\
Industry distance to frontier (IDF) & 615191 & 2.632 & 0.463 & 615190 & 2.974 & 0.586 \\
Firm distance to frontier (FDF) & 615191 & 9.207 & 0.691 & 615190 & 10.994 & 0.821 \\
Firm age (age) & 615191 & 1.899 & 0.798 & 615190 & 2.083 & 0.956 \\
Firm size (size) & 615191 & 10.341 & 1.238 & 615190 & 9.501 & 1.229 \\
Capital intensity (capital intensity) & 615191 & 3.653 & 1.300 & 615190 & 3.131 & 1.307 \\
Firm exit (exit) & 615191 & 0.096 & 0.294 & 615190 & 0.127 & 0.333 \\
Herfindahl-Hirschman Index (HHI) & 615191 & 0.013 & 0.019 & 615190 & 0.014 & 0.020 \\
State-owned enterprise (SOE) & 615191 & 0.063 & 0.244 & 615190 & 0.142 & 0.349 \\
Collective enterprise (COL) & 615191 & 0.364 & 0.481 & 615190 & 0.336 & 0.472 \\
Private-owned enterprise (POE) & 615191 & 0.435 & 0.496 & 615190 & 0.414 & 0.492 \\
Foreign-invested enterprise (FIE) & 615191 & 0.149 & 0.356 & 615190 & 0.123 & 0.328 \\
Marketization index (market) & 615191 & -2.592 & 0.272 & 615190 & -2.653 & 0.326 \\
\hline
\end{tabular}

Notes: the sample is split at the median of the firm distance measure (FDF); the 'close to frontier' subgroup consists of firms with firm-year observations near the technology frontier (less or equally distant to the frontier as the year-specific median of the distance distribution in the sample); and the 'far from frontier' subgroup includes firms with firm-year observations further behind the technology frontier (more distant to the frontier than the sample median). 
Table 3. Baseline results: import competition effects on TFP growth

\begin{tabular}{|c|c|c|c|c|c|c|}
\hline \multirow{2}{*}{ Dep var: TFP growth } & \multicolumn{3}{|c|}{ Industry distance measure (IDF) } & \multicolumn{3}{|c|}{ Firm distance measure (FDF) } \\
\hline & $(1)$ & $(2)$ & (3) & (4) & $(5)$ & $(6)$ \\
\hline \multirow[t]{2}{*}{ IMP } & $0.185 * * *$ & $0.185 * * *$ & $0.123 * *$ & $0.448 * * *$ & $0.449 * * *$ & $0.548 * * *$ \\
\hline & $(0.051)$ & $(0.051)$ & $(0.048)$ & $(0.092)$ & $(0.092)$ & $(0.088)$ \\
\hline \multirow[t]{2}{*}{$\mathrm{DF} \times \mathrm{IMP}$} & $-0.095 * * *$ & $-0.095 * * *$ & $-0.039 * *$ & $-0.056 * * *$ & $-0.056 * * *$ & $-0.056 * * *$ \\
\hline & $(0.019)$ & $(0.019)$ & $(0.017)$ & $(0.009)$ & $(0.009)$ & $(0.009)$ \\
\hline \multirow[t]{2}{*}{ DF } & $-0.012 * * *$ & $-0.012 * * *$ & 0.003 & $0.136 * * *$ & $0.136 * * *$ & $0.136 * * *$ \\
\hline & $(0.002)$ & $(0.002)$ & $(0.002)$ & $(0.001)$ & $(0.001)$ & $(0.001)$ \\
\hline \multirow[t]{2}{*}{ Age } & $-0.020 * * *$ & $-0.020 * * *$ & $-0.020 * * *$ & $-0.028 * * *$ & $-0.028 * * *$ & $-0.028 * * *$ \\
\hline & $(0.001)$ & $(0.001)$ & $(0.001)$ & $(0.001)$ & $(0.001)$ & $(0.001)$ \\
\hline \multirow[t]{2}{*}{ Size } & $0.071 * * *$ & $0.071 * * *$ & $0.071 * * *$ & $0.158 * * *$ & $0.158 * * *$ & $0.158 * * *$ \\
\hline & $(0.001)$ & $(0.001)$ & $(0.001)$ & $(0.001)$ & $(0.001)$ & $(0.001)$ \\
\hline \multirow{2}{*}{ Capital intensity } & $0.037 * * *$ & $0.037 * * *$ & $0.036^{* * *}$ & $0.068 * * *$ & $0.068 * * *$ & $0.068 * * *$ \\
\hline & $(0.001)$ & $(0.001)$ & $(0.001)$ & $(0.001)$ & $(0.001)$ & $(0.001)$ \\
\hline \multirow[t]{2}{*}{ Exit } & $-0.020 * * *$ & $-0.020 * * *$ & $-0.021 * * *$ & $-0.014 * * *$ & $-0.014 * * *$ & $-0.015 * * *$ \\
\hline & $(0.002)$ & $(0.002)$ & $(0.002)$ & $(0.002)$ & $(0.002)$ & $(0.002)$ \\
\hline \multirow[t]{2}{*}{ HHI } & $-0.216 * * *$ & $-0.217 * * *$ & -0.047 & $-0.354 * * *$ & $-0.354 * * *$ & $-0.147 * * *$ \\
\hline & $(0.042)$ & $(0.042)$ & $(0.036)$ & $(0.041)$ & $(0.041)$ & $(0.036)$ \\
\hline \multirow[t]{2}{*}{$\mathrm{SOE}$} & $-0.005 * *$ & $-0.005 * *$ & $-0.005 * *$ & $-0.014 * * *$ & $-0.014 * * *$ & $-0.013 * * *$ \\
\hline & $(0.002)$ & $(0.002)$ & $(0.002)$ & $(0.002)$ & $(0.002)$ & $(0.002)$ \\
\hline \multirow[t]{2}{*}{$\mathrm{COL}$} & $-0.003 * * *$ & $-0.003 * * *$ & $-0.004 * * *$ & $-0.004 * * *$ & $-0.004 * * *$ & $-0.004 * * *$ \\
\hline & $(0.001)$ & $(0.001)$ & $(0.001)$ & $(0.001)$ & $(0.001)$ & $(0.001)$ \\
\hline \multirow[t]{2}{*}{ FIE } & -0.004 & -0.004 & $-0.004 *$ & -0.003 & -0.003 & -0.003 \\
\hline & $(0.002)$ & $(0.002)$ & $(0.002)$ & $(0.002)$ & $(0.002)$ & $(0.002)$ \\
\hline \multirow[t]{2}{*}{ Market } & $0.024 * * *$ & $0.024 * * *$ & $0.024 * * *$ & $0.055 * * *$ & $0.055 * * *$ & $0.052 * * *$ \\
\hline & $(0.007)$ & $(0.007)$ & $(0.007)$ & $(0.007)$ & $(0.007)$ & $(0.007)$ \\
\hline Year fixed effects & Yes & Yes & Yes & Yes & Yes & Yes \\
\hline Firm fixed effects & Yes & Yes & Yes & Yes & Yes & Yes \\
\hline Province fixed effects & No & Yes & Yes & No & Yes & Yes \\
\hline Industry fixed effects & No & No & Yes & No & No & Yes \\
\hline Max of DF & 5.957 & 5.957 & 5.957 & 14.090 & 14.090 & 14.090 \\
\hline Min of DF & 1.041 & 1.041 & 1.041 & 7.015 & 7.015 & 7.015 \\
\hline Mean of DF & 2.803 & 2.803 & 2.803 & 10.100 & 10.100 & 10.100 \\
\hline Adj- $R^{2}$ & 0.027 & 0.027 & 0.071 & 0.092 & 0.092 & 0.135 \\
\hline Observations & 945387 & 945387 & 945387 & 945387 & 945387 & 945387 \\
\hline
\end{tabular}

Notes: standard errors are reported in parentheses, which are clustered at the firm level; $* * * \mathrm{p}<0.01, * * \mathrm{p}<0.05, * \mathrm{p}<0.1$. 
Table 4. Import competition effects on TFP growth by trade regimes

\begin{tabular}{l|ccc|ccc}
\hline \multirow{2}{*}{ Dep var: TFP growth } & \multicolumn{2}{|c|}{ Industry distance measure (IDF) } & \multicolumn{2}{c}{ Firm distance measure (FDF) } \\
\cline { 2 - 7 } & $(1)$ & $(2)$ & $(3)$ & $(4)$ & $(5)$ & $(6)$ \\
\hline Ordinary IMP & $2.477^{* * *}$ & & $3.604^{* * *}$ & $9.952^{* * *}$ & & $8.715^{* * *}$ \\
& $(0.956)$ & & $(1.051)$ & $(1.876)$ & $(2.013)$ \\
DF $\times$ Ordinary IMP & $-0.928^{* * *}$ & & $-1.290^{* * *}$ & $-0.996^{* * *}$ & & $-0.828^{* * *}$ \\
& $(0.359)$ & & $(0.388)$ & $(0.186)$ & & $(0.200)$ \\
Processing IMP & & $-1.698^{*}$ & $-3.362^{* * *}$ & & $4.683^{* * *}$ & 2.033 \\
& & $(0.978)$ & $(1.091)$ & & $(1.654)$ & $(1.782)$ \\
DF $\times$ Processing IMP & & $0.544^{*}$ & $1.082^{* * *}$ & & $-0.564^{* * *}$ & $-0.316^{*}$ \\
& & $(0.317)$ & $(0.351)$ & & $(0.156)$ & $(0.169)$ \\
DF & $0.003^{*}$ & 0.001 & 0.003 & $0.136^{* * *}$ & $0.136^{* * *}$ & $0.136^{* * *}$ \\
& $(0.002)$ & $(0.002)$ & $(0.002)$ & $(0.001)$ & $(0.001)$ & $(0.001)$ \\
\hline Adj- $\mathrm{R}^{2}$ & 0.071 & 0.071 & 0.071 & 0.135 & 0.135 & 0.136 \\
Observations & 945387 & 945387 & 945387 & 945387 & 945387 & 945387 \\
\hline
\end{tabular}

Notes: Ordinary IMP is the ordinary-trade import penetration ratio and Processing IMP is the processing-trade import penetration ratio; standard errors are reported in parentheses, which are clustered at the firm level; all other control variables are included but not reported to save space; all year, firm, province, and industry fixed effects are included; *** $\mathrm{p}<0.01, * *$ $\mathrm{p}<0.05, * \mathrm{p}<0.1$. 
Table 5. Import competition effects on TFP growth across ownership groups

\begin{tabular}{|c|c|c|c|c|c|c|c|c|}
\hline \multirow{2}{*}{$\begin{array}{l}\text { Dep var: } \\
\text { TFP growth }\end{array}$} & \multicolumn{4}{|c|}{ Industry distance measure (IDF) } & \multicolumn{4}{|c|}{ Firm distance measure (FDF) } \\
\hline & $\begin{array}{l}(1) \\
\text { SOEs }\end{array}$ & $\begin{array}{c}\text { (2) } \\
\text { Collective firms }\end{array}$ & $\begin{array}{c}\text { (3) } \\
\text { Private firms }\end{array}$ & $\begin{array}{c}\text { (4) } \\
\text { Foreign firms }\end{array}$ & $\begin{array}{c}(5) \\
\text { SOEs }\end{array}$ & $\begin{array}{c}\text { (6) } \\
\text { Collective firms }\end{array}$ & $\begin{array}{c}\text { (7) } \\
\text { Private firms }\end{array}$ & $\begin{array}{c}(8) \\
\text { Foreign firms }\end{array}$ \\
\hline \multirow[t]{2}{*}{ IMP } & 0.041 & $0.222 * * *$ & $0.238 * * *$ & 0.056 & 0.756 & $0.517 * * *$ & $0.435^{* *}$ & 0.408 \\
\hline & $(0.136)$ & $(0.084)$ & $(0.092)$ & $(0.128)$ & $(0.513)$ & $(0.176)$ & $(0.185)$ & $(0.486)$ \\
\hline \multirow{2}{*}{$\mathrm{DF} \times \mathrm{IMP}$} & -0.024 & $-0.072 * *$ & $-0.081 * *$ & -0.009 & -0.072 & $-0.052 * * *$ & $-0.045 * *$ & -0.043 \\
\hline & $(0.046)$ & $(0.030)$ & $(0.033)$ & $(0.047)$ & $(0.060)$ & $(0.017)$ & $(0.019)$ & $(0.048)$ \\
\hline \multirow[t]{2}{*}{ DF } & 0.006 & 0.001 & 0.000 & 0.006 & $0.123 * * *$ & $0.142 * * *$ & $0.154 * * *$ & $0.106^{* * *}$ \\
\hline & $(0.005)$ & $(0.003)$ & $(0.003)$ & $(0.006)$ & $(0.003)$ & $(0.002)$ & $(0.002)$ & $(0.002)$ \\
\hline Max of DF & 5.957 & 4.954 & 4.798 & 4.792 & 14.090 & 14.089 & 14.090 & 14.088 \\
\hline Min of DF & 1.041 & 1.041 & 1.040 & 1.039 & 7.014 & 7.013 & 7.015 & 7.014 \\
\hline Mean of DF & 3.029 & 2.833 & 2.748 & 2.740 & 10.851 & 10.058 & 10.021 & 9.913 \\
\hline Adj-R ${ }^{2}$ & 0.066 & 0.073 & 0.076 & 0.080 & 0.134 & 0.142 & 0.144 & 0.125 \\
\hline Observations & 109460 & 338346 & 379415 & 129242 & 109460 & 338346 & 379415 & 129242 \\
\hline
\end{tabular}

Notes: standard errors are reported in parentheses, which are clustered at the firm level; all other control variables are included but not reported to save space; all year, firm, province, and industry fixed effects are included; $* * * \mathrm{p}<0.01, * * \mathrm{p}<0.05,{ }^{*} \mathrm{p}<0.1$. 
Table 6. Import competition effects on TFP growth by origin of imports

\begin{tabular}{l|ccc|ccc}
\hline \multirow{2}{*}{ Dep var: TFP growth } & \multicolumn{2}{|c|}{ Industry distance measure (IDF) } & \multicolumn{2}{c}{ Firm distance measure (FDF) } \\
\cline { 2 - 6 } & $(1)$ & $(2)$ & $(3)$ & $(4)$ & $(5)$ & $(6)$ \\
\hline High-income IMP & $0.115^{*}$ & & $0.085^{*}$ & $0.412^{* * *}$ & & $0.464^{* * *}$ \\
& $(0.064)$ & & $(0.048)$ & $(0.109)$ & $(0.124)$ \\
DF $\times$ High-income IMP & $-0.068^{* * *}$ & & $-0.059^{* *}$ & $-0.051^{* * *}$ & & $-0.058^{* * *}$ \\
& $(0.023)$ & & $(0.026)$ & $(0.011)$ & & $(0.012)$ \\
Low-income IMP & & 0.829 & -0.105 & & -2.278 & -3.686 \\
& & $(1.725)$ & $(1.714)$ & & $(2.411)$ & $(2.375)$ \\
DF $\times$ Low-income IMP & & -0.409 & 0.006 & & 0.192 & 0.369 \\
& & $(0.598)$ & $(0.588)$ & & $(0.239)$ & $(0.233)$ \\
DF & $0.004^{*}$ & 0.002 & $0.004^{*}$ & $0.136^{* * *}$ & $0.137^{* * *}$ & $0.137^{* * *}$ \\
& $(0.002)$ & $(0.002)$ & $(0.002)$ & $(0.001)$ & $(0.001)$ & $(0.001)$ \\
\hline Adj- ${ }^{2}$ & 0.071 & 0.070 & 0.071 & 0.135 & 0.135 & 0.135 \\
Observations & 945387 & 945387 & 945387 & 945387 & 945387 & 945387 \\
\hline
\end{tabular}

Notes: High-income IMP is the import penetration ratio of imports from high-income countries and Low-income IMP is the import penetration ratio of imports from low-income countries; the high- and low-income country classification is made by comparing the GDP per capita in 2000 (constant 2005 US\$, data from World Development Indicator) between China and other countries, i.e. countries with GDP per capita higher than China are referred to as high-income countries, and those with GDP per capita lower than China are referred to as low-income countries; standard errors are reported in parentheses, which are clustered at the firm level; all other control variables are included but not reported to save space; all year, firm, province, and industry fixed effects are included; *** $\mathrm{p}<0.01, * * \mathrm{p}<0.05, * \mathrm{p}<0.1$.

Table 7. Import competition effects on TFP growth (an alternative control for FDI)

\begin{tabular}{l|ccc|ccc}
\hline \multirow{2}{*}{ Dep var: TFP growth } & \multicolumn{3}{|c|}{ Industry distance measure (IDF) } & \multicolumn{3}{c}{ Firm distance measure (FDF) } \\
\cline { 2 - 7 } & $(1)$ & $(2)$ & $(3)$ & $(4)$ & $(5)$ & $(6)$ \\
\hline IMP & $0.173^{* * *}$ & $0.174^{* * *}$ & $0.118^{* *}$ & $0.465^{* * *}$ & $0.467^{* * *}$ & $0.556^{* * *}$ \\
& $(0.051)$ & $(0.051)$ & $(0.048)$ & $(0.093)$ & $(0.093)$ & $(0.089)$ \\
DF $\times$ IMP & $-0.089^{* * *}$ & $-0.089^{* * *}$ & $-0.036^{* *}$ & $-0.057^{* * *}$ & $-0.057^{* * *}$ & $-0.056^{* * *}$ \\
& $(0.019)$ & $(0.019)$ & $(0.017)$ & $(0.009)$ & $(0.009)$ & $(0.009)$ \\
DF & $-0.011^{* * *}$ & $-0.012^{* * *}$ & $-0.003^{*}$ & $0.136^{* * *}$ & $0.136^{* * *}$ & $0.136^{* * *}$ \\
& $(0.002)$ & $(0.002)$ & $(0.002)$ & $(0.001)$ & $(0.001)$ & $(0.001)$ \\
FDI & $0.035^{* * *}$ & $0.036^{* * *}$ & $0.035^{* * *}$ & $0.037^{* * *}$ & $0.038^{* * *}$ & $0.033^{* * *}$ \\
& $(0.005)$ & $(0.005)$ & $(0.005)$ & $(0.005)$ & $(0.005)$ & $(0.005)$ \\
\hline Year fixed effects & Yes & Yes & Yes & Yes & Yes & Yes \\
Firm fixed effects & Yes & Yes & Yes & Yes & Yes & Yes \\
Province fixed effects & No & Yes & Yes & No & Yes & Yes \\
Industry fixed effects & No & No & Yes & No & No & Yes \\
\hline Adj- $\mathrm{R}^{2}$ & 0.027 & 0.027 & 0.070 & 0.092 & 0.092 & 0.134 \\
Observation & 945387 & 945387 & 945387 & 945387 & 945387 & 945387 \\
\hline
\end{tabular}

Notes: FDI is the FDI intensity measured by the ratio of foreign investment to total assets as in Fu and Gong (2011); the three ownership variables are dropped to avoid multi-collinearity; standard errors are reported in parentheses, which are clustered at the firm level; all other control variables are included but not reported to save space; $* * * \mathrm{p}<0.01, * * \mathrm{p}<0.05, * \mathrm{p}<0.1$. 
Table 8. Import competition effects on TFP growth using two-stage IV estimation

\begin{tabular}{l|ccc|ccc}
\hline \multirow{2}{*}{ Dep var: TFP growth } & \multicolumn{2}{|c|}{ Industry distance measure (IDF) } & \multicolumn{3}{c}{ Firm distance measure (FDF) } \\
\cline { 2 - 7 } & $(1)$ & $(2)$ & $(3)$ & $(4)$ & $(5)$ & $(6)$ \\
\hline IMP & $0.105^{* *}$ & $0.105^{* *}$ & 0.032 & $0.172^{* * *}$ & $0.172^{* * *}$ & $0.227^{* * *}$ \\
& $(0.050)$ & $(0.050)$ & $(0.043)$ & $(0.063)$ & $(0.063)$ & $(0.056)$ \\
DF $\times$ IMP & $-0.056^{* * *}$ & $-0.056^{* * *}$ & -0.009 & $-0.023^{* * *}$ & $-0.023^{* * *}$ & $-0.023^{* * *}$ \\
& $(0.018)$ & $(0.018)$ & $(0.015)$ & $(0.006)$ & $(0.006)$ & $(0.006)$ \\
DF & $-0.011^{* * *}$ & $-0.011^{* * *}$ & $-0.004^{* * *}$ & $0.058^{* * *}$ & $0.058^{* * *}$ & $0.057^{* * *}$ \\
& $(0.002)$ & $(0.002)$ & $(0.002)$ & $(0.001)$ & $(0.001)$ & $(0.001)$ \\
\hline Year fixed effects & Yes & Yes & Yes & Yes & Yes & Yes \\
Firm fixed effects & Yes & Yes & Yes & Yes & Yes & Yes \\
Province fixed effects & No & Yes & Yes & No & Yes & Yes \\
Industry fixed effects & No & No & Yes & No & No & Yes \\
\hline Adj-R $\mathrm{R}^{2}$ & 0.070 & 0.070 & 0.173 & 0.139 & 0.139 & 0.240 \\
Observation & 945387 & 945387 & 945387 & 945387 & 945387 & 945387 \\
\hline
\end{tabular}

Notes: the one-year lag of product-level output tariffs obtained from WTO are used as instruments for the import penetration variable (IMP); the US industry-level wage and capital labor ratio are employed as instruments to the distance variable (DF); standard errors are reported in parentheses, which are clustered at the firm level; all other control variables are included but not reported to save space; $* * * \mathrm{p}<0.01, * * \mathrm{p}<0.05, * \mathrm{p}<0.1$ 
Figure 1. Innovation and competition: the inverted-U relationship

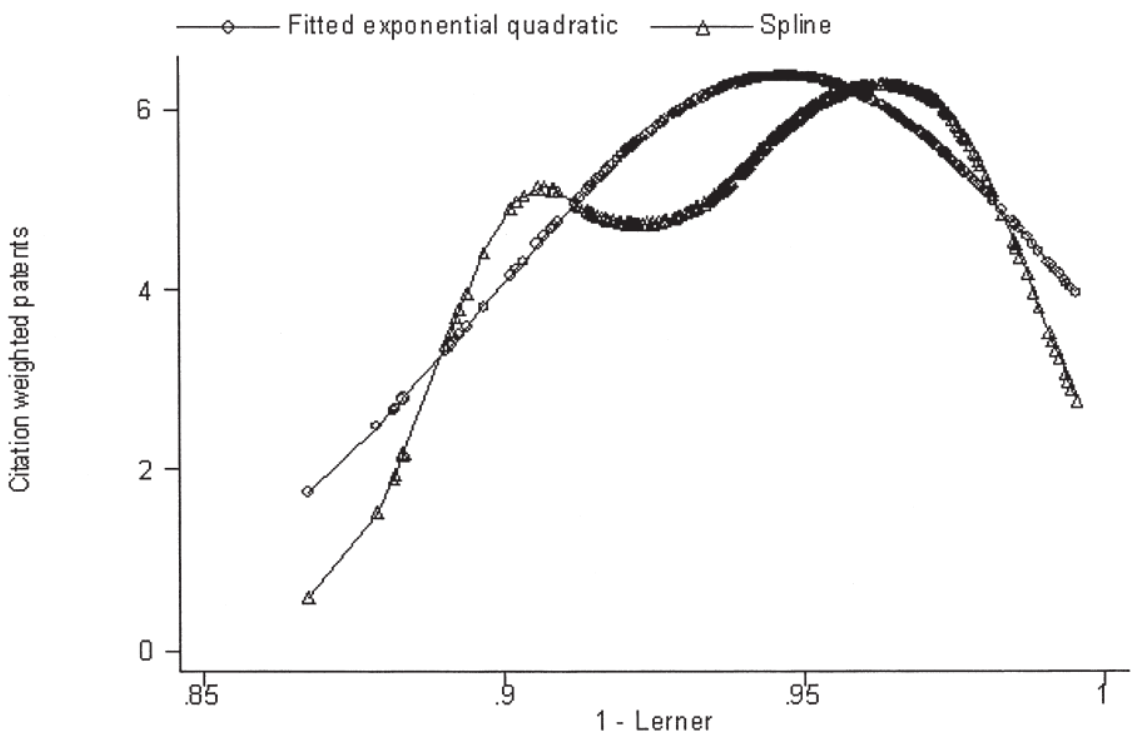

Notes: this figure plots a measure of competition on the $x$-axis against a measure of innovation (the citationweighted patents) on the $y$-axis. Each-point represents an industry-year. The circles show an exponential quadratic curve and the triangles show a nonparametric spine.

Source: Aghion et al. (2005).

Figure 2. China's trade liberalization: imports, exports and import penetration

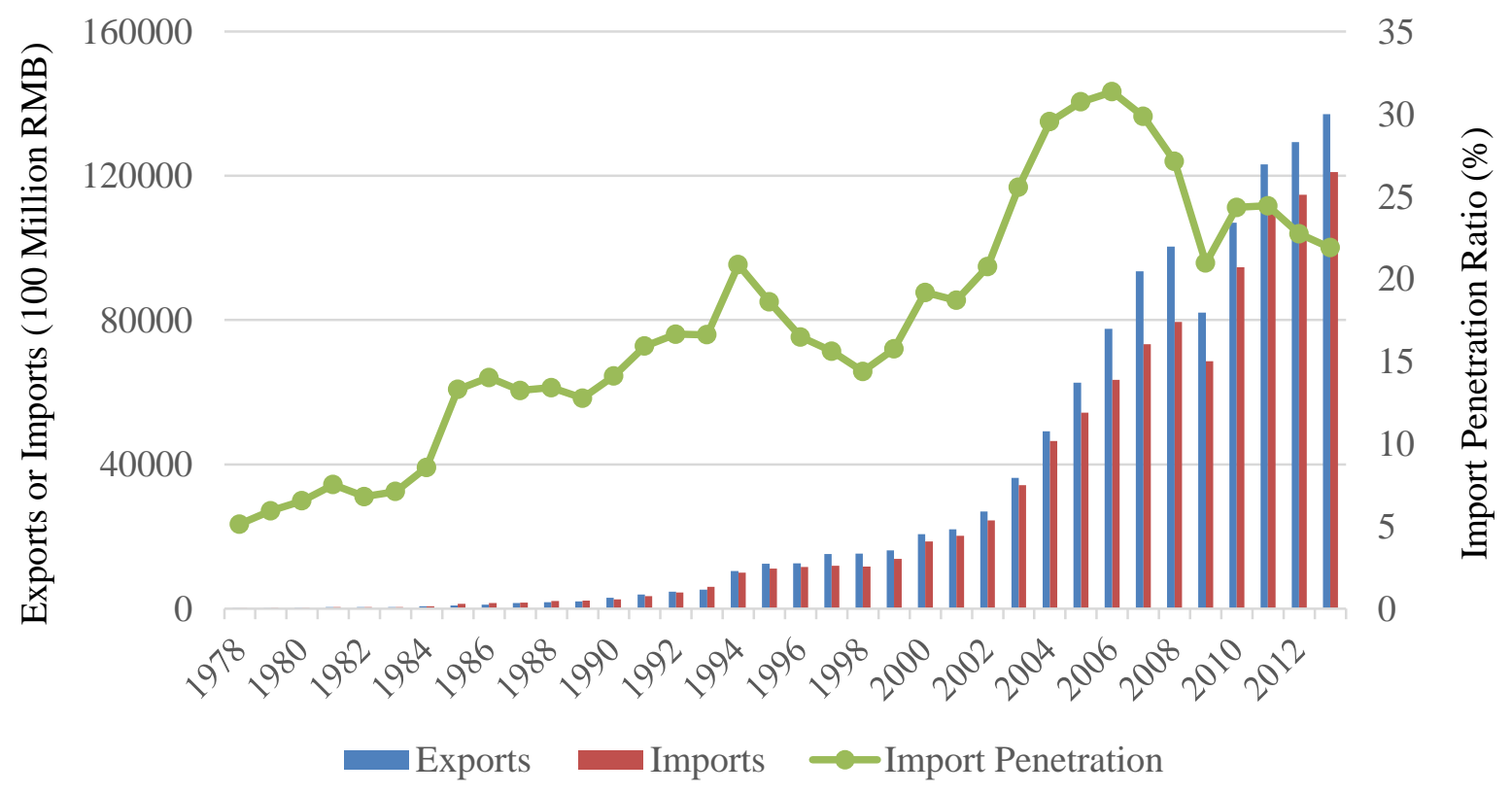

Notes: exports and imports are in absolute term to reflect trade volumes; import penetration ratio is the ratio of imports to the gross domestic product (GDP) adjusted for the foreign trade balance (difference between exports and imports) in order to reflect the importance of imports in the domestic economy.

Data source: China Statistical Yearbook (various issues). 
Figure 3. China's imports by trade regimes

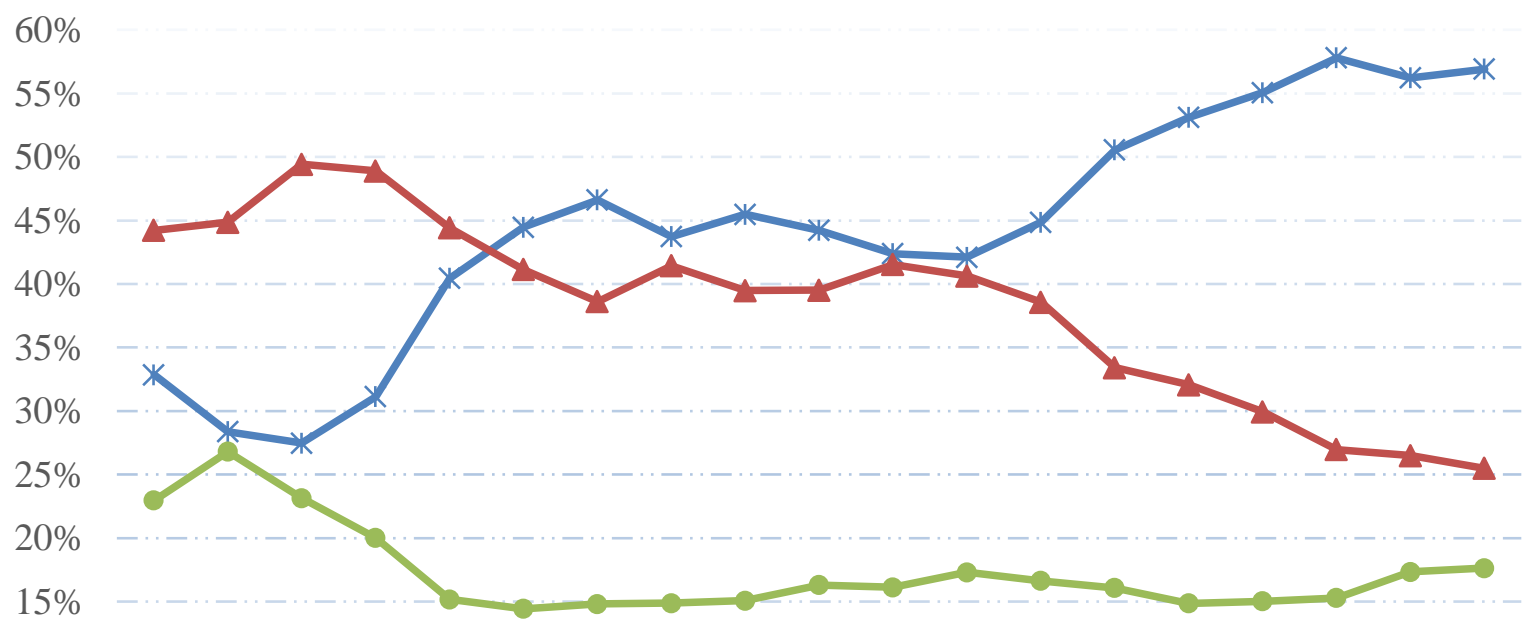

$10 \%$

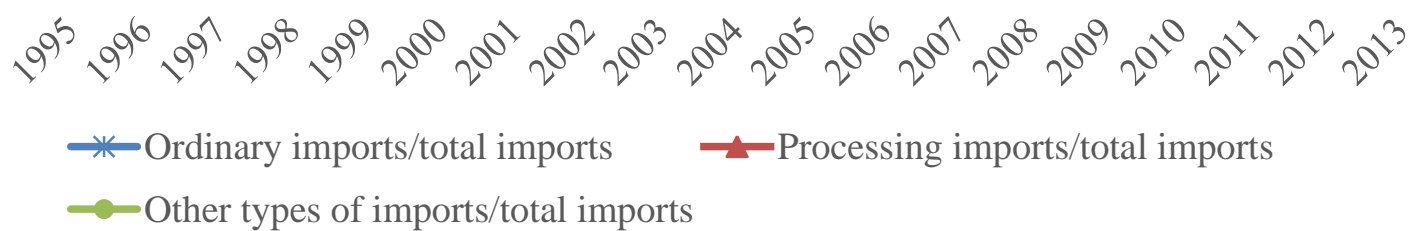

Notes: Ordinary imports refer to imports under the ordinary trade regime; processing imports refer to imports under the processing trade regime, which consist of 'pure assembly trade' and 'processing with imported materials trade'; other types of imports include imports under 'consignment trade', 'compensatory trade', 'small-amount border trade', 'exports of foreign contracted projects', 'barter trade', 'tax-free merchandise (goods) sold (bought) in foreign currencies', 'inbound and outbound goods in bonded warehouse', 'storage of transit goods in bonded warehouse' , 'goods from non-rewarded assistance and donation from other countries and international organizations' and other types of trade.

Data source: China Customs Statistics Monthly Report (various issues). 
Figure 4. China's imports by countries of origin

40

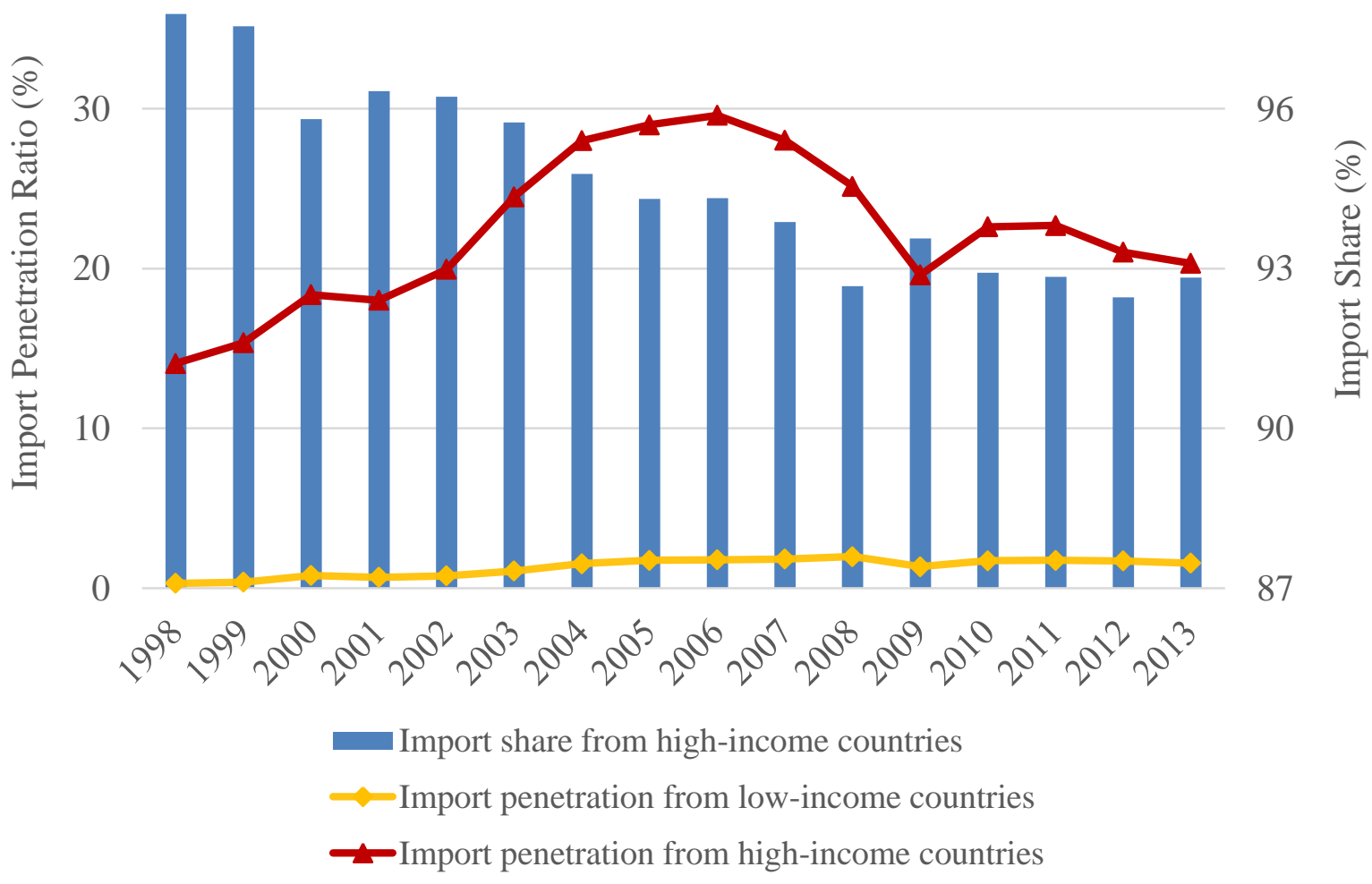

Notes: the high- and low-income country classification is made by comparing the GDP per capita in 2000 (constant 2005 US\$, data from World Development Indicator) between China and other countries, i.e. countries with GDP per capita higher than China are referred to as high-income countries, and those with GDP per capita lower than China are referred to as low-income countries; the import penetration ratio is then computed for these two groups of countries. The import share from high-income countries is the ratio between import volumes from high-income countries and the total import volumes in China.

Data source: China Statistical Yearbook (various issues) 
Figure 5. China's imports by ownerships

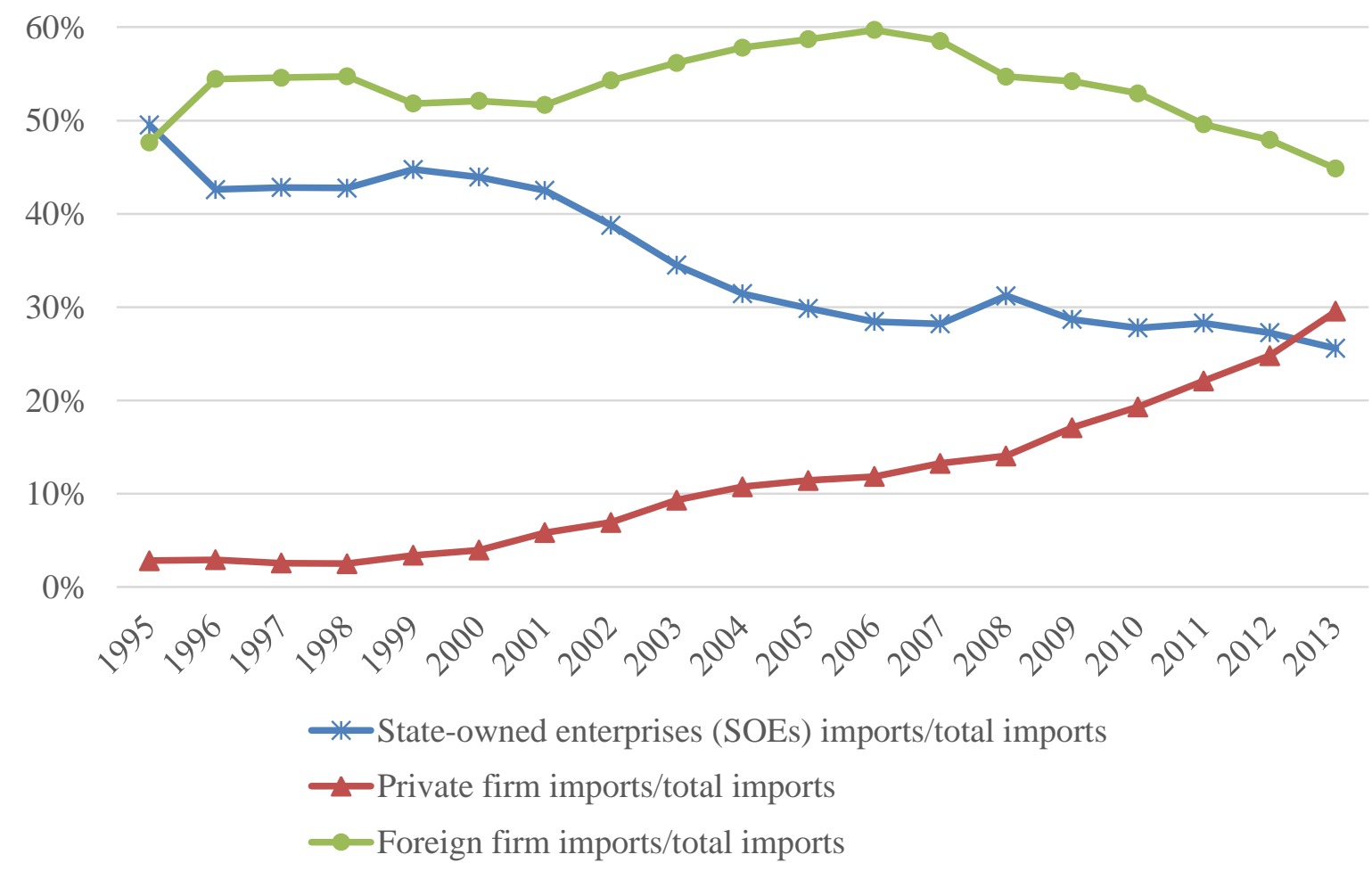

Data source: China Customs Statistics Monthly Report (various issues). 


\section{Online Appendix 1. Industry-level import penetration information}

The industry-level import penetration ratio is also important as it reflects a country's industrial and trade structure. Using our own micro-level data, we compute the import penetration ratio in 2-digit Chinese industrial sectors during the period of 2000-06 in Appendix Table A1. It is interesting to see that there exist significant cross-sectional and time-series variations. For instance, the important penetration ratio is high and rising for a number of sectors producing industrial goods (such as electrical machinery and equipment manufacturing; electronic and communication equipment manufacturing etc.), but the ratio is low and declining for sectors producing primary goods and labor-intensive products (such as food processing, beverage manufacturing, and textile etc.). This pattern corresponds well to the fact that China is a big net importer of intermediate capital- and skill-intensive goods, and a big net exporter of primary and final labor-intensive products, which is consistent with the predictions of the comparative advantage argument. The significant heterogeneity of industry-level import penetration ratio may also indicate different levels of protection across sectors in China, i.e. high tariffs in sectors like food and beverages but low tariffs in other sectors such as electronic equipment. 
Table A1. Import penetration ratio in 2-digit Chinese industrial sectors (2000-06)

\begin{tabular}{|c|c|c|c|c|c|c|c|c|}
\hline Industry code & Industry name & 2000 & 2001 & 2002 & 2003 & 2004 & 2005 & 2006 \\
\hline 13 & Food processing industry & 0.075 & 0.066 & 0.068 & 0.075 & 0.076 & 0.056 & 0.052 \\
\hline 14 & Food manufacturing industry & 0.037 & 0.040 & 0.035 & 0.032 & 0.032 & 0.025 & 0.023 \\
\hline 15 & Beverage manufacturing industry & 0.007 & 0.006 & 0.005 & 0.005 & 0.005 & 0.005 & 0.006 \\
\hline 16 & Tobacco processing industry & 0.015 & 0.017 & 0.013 & 0.015 & 0.014 & 0.019 & 0.022 \\
\hline 17 & Textile industry & 0.126 & 0.123 & 0.101 & 0.092 & 0.075 & 0.061 & 0.049 \\
\hline 18 & Clothing and other fiber products manufacturing & 0.049 & 0.046 & 0.040 & 0.039 & 0.040 & 0.030 & 0.026 \\
\hline 19 & Leather, fur, down and down products industry & 0.079 & 0.066 & 0.072 & 0.064 & 0.068 & 0.049 & 0.043 \\
\hline 20 & Timber processing, bamboo, cane, palm fiber and straw products industry & 0.129 & 0.087 & 0.086 & 0.090 & 0.070 & 0.048 & 0.031 \\
\hline 21 & Furniture manufacturing industry & 0.060 & 0.075 & 0.076 & 0.104 & 0.099 & 0.069 & 0.058 \\
\hline 22 & Paper and paper products industry & 0.173 & 0.157 & 0.144 & 0.133 & 0.11 & 0.088 & 0.073 \\
\hline 23 & Printing and record medium reproduction industry & 0.032 & 0.033 & 0.029 & 0.026 & 0.026 & 0.025 & 0.024 \\
\hline 24 & Educational and sports goods industry & 0.290 & 0.312 & 0.339 & 0.348 & 0.371 & 0.359 & 0.325 \\
\hline 25 & Petroleum processing and coking industry & 0.033 & 0.03 & 0.138 & 0.148 & 0.161 & 0.158 & 0.184 \\
\hline 26 & Chemical materials and chemical products manufacturing industry & 0.317 & 0.331 & 0.317 & 0.324 & 0.319 & 0.297 & 0.271 \\
\hline 27 & Pharmaceutical manufacturing industry & 0.061 & 0.073 & 0.068 & 0.070 & 0.072 & 0.068 & 0.065 \\
\hline 28 & Manufacture of chemical fibers industry & 0.153 & 0.164 & 0.158 & 0.143 & 0.127 & 0.102 & 0.072 \\
\hline 29 & Rubber product industry & 0.076 & 0.084 & 0.076 & 0.102 & 0.103 & 0.094 & 0.111 \\
\hline 30 & Plastic products industry & 0.131 & 0.126 & 0.120 & 0.128 & 0.126 & 0.125 & 0.115 \\
\hline 31 & Non-metallic mineral products industry & 0.045 & 0.046 & 0.043 & 0.043 & 0.041 & 0.035 & 0.030 \\
\hline 32 & Ferrous metal smelting and rolling processing industry & 0.131 & 0.129 & 0.143 & 0.148 & 0.116 & 0.111 & 0.088 \\
\hline 33 & Non-ferrous metal smelting and rolling processing industry & 0.225 & 0.227 & 0.209 & 0.216 & 0.193 & 0.193 & 0.160 \\
\hline 34 & Fabricated metal products industry & 0.132 & 0.135 & 0.134 & 0.134 & 0.145 & 0.123 & 0.114 \\
\hline 35 & General machinery manufacturing industry & 0.353 & 0.377 & 0.362 & 0.373 & 0.355 & 0.313 & 0.283 \\
\hline 36 & Special equipment manufacturing industry & 0.371 & 0.452 & 0.421 & 0.426 & 0.404 & 0.368 & 0.329 \\
\hline 37 & Transportation equipment manufacturing industry & 0.114 & 0.177 & 0.142 & 0.171 & 0.15 & 0.145 & 0.172 \\
\hline 39 & Weapons and ammunition industry & 0.033 & 0.034 & 0.050 & 0.037 & 0.034 & 0.031 & 0.028 \\
\hline 40 & Electrical machinery and equipment manufacturing & 0.464 & 0.511 & 0.607 & 0.686 & 0.858 & 0.903 & 1.079 \\
\hline 41 & Electronic and communication equipment manufacturing industry & 0.494 & 0.555 & 0.573 & 0.702 & 0.746 & 0.737 & 0.705 \\
\hline 42 & Instrumentation and culture, office machinery manufacturing industry & 0.152 & 0.148 & 0.122 & 0.113 & 0.114 & 0.090 & 0.075 \\
\hline
\end{tabular}

Notes: industry code is the 2-digit Chinese Standard Industrial Classification (CSIC) code. 


\section{Online Appendix 2. TFP estimation: methods and results}

We construct the measure of firm-level TFP using the semi-parametric Olley and Pakes (1996) approach which alleviates both the selection bias and simultaneity bias (between input choices and productivity shocks). Another advantage of Olley-Pakes method is the flexible characterization of productivity, only assuming that it evolves according to a Markov process (Van Biesebroeck, 2007). Thus, assuming a Cobb-Douglas production function, the production function is

$$
y_{i j t}=\beta_{0}+\beta_{k} k_{i j t}+\beta_{l} l_{i j t}+w_{i j t}+\varepsilon_{i j t}
$$

where $y_{i j t}, k_{i j t}$, and $l_{i j t}$ refer to the natural logarithm of value added ${ }^{1}$, capital input ${ }^{2}$ and labor input $^{3}$ of firm $i$ in industry $j$ at time $t ; w_{i j t}$ represents a productivity difference known to the firm, but unobservable to us; and $\varepsilon_{i j t}$ is either measurement error or a shock to productivity which is not forecastable during the period in which labor can be adjusted.

Our approach is based on the recent development in the application of the Olley-Pakes method (for instance, Amiti and Konings, 2007; Brandt et al., 2012; Feenstra et al., 2013). First, we use different price deflators for inputs, outputs and investment. It is known in the productivity literature that ideally one would use firm-specific price deflators when constructing TFP. Since such information is not available in the data, we use different industry-specific price deflators for inputs, outputs and investment, which are directly drawn from Brandt et al. (2012). This implies that our TFP measure is a revenue-based productivity measure (TFPR) as introduced by Foster et al. (2008), which may capture both technical efficiency and price-cost markups. Following Pavcnik (2002), we control for firm-specific markups with firm fixed effects in the estimation. Second, we use the perpetual inventory method to compute the real investment variable, where the depreciation rate of physical capital is based on firms' reported actual depreciation figure rather than arbitrary assumptions. Appendix Table A2 reports the estimated coefficients of the production function and the associated log of TFP by industry.

\footnotetext{
${ }^{1}$ The value added is defined as sales minus intermediate inputs plus value added tax.

${ }^{2}$ Capital input is computed using the perpetual inventory method following Brandt et al. (2012).

${ }^{3}$ Labor input is total employment.
} 
Table A2. TFP Estimates using Olley-Pakes approach

\begin{tabular}{|c|c|c|c|c|c|c|}
\hline Industry code & Industry name & Capital & Std. Dev. & Labor & Std. Dev. & TFP \\
\hline 13 & Food processing industry & $0.464 * * *$ & 0.014 & $0.497 * * *$ & 0.009 & 4.009 \\
\hline 14 & Food manufacturing industry & $0.641 * * *$ & 0.021 & $0.593 * * *$ & 0.011 & 4.120 \\
\hline 15 & Beverage manufacturing industry & $0.628 * * *$ & 0.037 & $0.481 * * *$ & 0.017 & 5.174 \\
\hline 16 & Tobacco processing industry & $0.625 * * *$ & 0.128 & $0.386 * * *$ & 0.072 & 8.517 \\
\hline 17 & Textile industry & $0.403 * * *$ & 0.013 & $0.415 * * *$ & 0.007 & 3.393 \\
\hline 18 & Clothing and other fiber products manufacturing & $0.357 * * *$ & 0.012 & $0.542 * * *$ & 0.008 & 4.076 \\
\hline 19 & Leather, fur, down and down products industry & $0.344 * * *$ & 0.017 & $0.504 * * *$ & 0.013 & 4.386 \\
\hline 20 & Timber processing, bamboo, cane, palm fiber and straw products industry & $0.451 * * *$ & 0.027 & $0.455 * * *$ & 0.015 & 3.754 \\
\hline 21 & Furniture manufacturing industry & $0.429 * * *$ & 0.051 & $0.681 * * *$ & 0.015 & 3.922 \\
\hline 22 & Paper and paper products industry & $0.503 * * *$ & 0.043 & $0.376 * * *$ & 0.011 & 4.171 \\
\hline 23 & Printing and record medium reproduction industry & $0.814 * * *$ & 0.026 & $0.396 * * *$ & 0.015 & 4.495 \\
\hline 24 & Educational and sports goods industry & $0.259 * * *$ & 0.061 & $0.523 * * *$ & 0.016 & 3.424 \\
\hline 25 & Petroleum processing and coking industry & $0.351 * * *$ & 0.072 & $0.355^{* * *}$ & 0.028 & 3.950 \\
\hline 26 & Chemical materials and chemical products manufacturing industry & $0.458 * * *$ & 0.036 & $0.362 * * *$ & 0.009 & 3.677 \\
\hline 27 & Pharmaceutical manufacturing industry & $0.534 * * *$ & 0.019 & $0.370 * * *$ & 0.017 & 4.489 \\
\hline 28 & Manufacture of chemical fibers industry & $0.505 * * *$ & 0.054 & $0.361 * * *$ & 0.029 & 5.157 \\
\hline 29 & Rubber product industry & $0.472 * * *$ & 0.043 & $0.392 * * *$ & 0.019 & 4.159 \\
\hline 30 & Plastic products industry & $0.475 * * *$ & 0.056 & $0.389 * * *$ & 0.009 & 3.431 \\
\hline 31 & Non-metallic mineral products industry & $0.618 * * *$ & 0.015 & $0.284 * * *$ & 0.008 & 3.434 \\
\hline 32 & Ferrous metal smelting and rolling processing industry & $0.466 * * *$ & 0.021 & $0.459 * * *$ & 0.012 & 4.136 \\
\hline 33 & Non-ferrous metal smelting and rolling processing industry & $0.382 * * *$ & 0.047 & $0.434 * * *$ & 0.023 & 4.193 \\
\hline 34 & Fabricated metal products industry & $0.425 * * *$ & 0.018 & $0.440 * * *$ & 0.008 & 3.718 \\
\hline 35 & General machinery manufacturing industry & $0.492 * * *$ & 0.015 & $0.391 * * *$ & 0.011 & 4.080 \\
\hline 36 & Special equipment manufacturing industry & $0.674 * * *$ & 0.019 & $0.400 * * *$ & 0.012 & 3.258 \\
\hline 37 & Transportation equipment manufacturing industry & $0.631 * * *$ & 0.032 & $0.507 * * *$ & 0.009 & 4.050 \\
\hline 39 & Weapons and ammunition industry & $0.467 * * *$ & 0.022 & $0.452 * * *$ & 0.008 & 4.212 \\
\hline 40 & Electrical machinery and equipment manufacturing & $0.453 * * *$ & 0.028 & $0.509 * * *$ & 0.010 & 4.392 \\
\hline 41 & Electronic and communication equipment manufacturing industry & $0.528 * * *$ & 0.054 & $0.418 * * *$ & 0.018 & 3.866 \\
\hline 42 & Instrumentation and culture, office machinery manufacturing industry & $0.353 * * *$ & 0.019 & $0.469 * * *$ & 0.012 & 3.596 \\
\hline
\end{tabular}

Notes: industry code is the 2-digit Chinese Standard Industrial Classification (CSIC) code; $* * * \mathrm{p}<0.01, * * \mathrm{p}<0.05, * \mathrm{p}<0.1$. 


\section{Online Appendix 3. Dataset merging techniques and outcomes}

The difficulty of merging the NBS and Customs datasets lies in the absence of a common firm identifier shared by both datasets. We therefore rely on other firm characteristics such as firm name, telephone number, zip code, and firm address to achieve the best possible match of two datasets. Appendix Table A3(a) presents a brief summary of the datasets. We find that the number of exporting firms in the NBS dataset is much smaller than that in the Customs dataset ${ }^{4}$. There are two explanations for this discrepancy. First, most trading firms are quite small, so that they are not included in the 'above-scale' NBS dataset (Yu, 2014). Second, the NBS dataset covers manufacturing firms only, whereas the Customs dataset consists of trading firms in all sectors in China such as manufacturing, agriculture, service, and so on. During the period of 2000-06, the number of exporting firms in our merged dataset accounts for $58.5 \%$ of total exporting firms in the NBS dataset on average.

We also compute the representativeness of our merged sample compared with the full-sample NBS data. Appendix Table A3(b) shows how much of total sales, exports and employment are accounted for by the merged data each year during 2000-06. On average, our merged data covers $44 \%$ of total sales, $74 \%$ of total exports and $36.4 \%$ of total employment in the firm-level NBS data. Appendix Table A3(c) shows that our merged sample has higher means of sales, exports and number of employees than the corresponding figures in the full-sample NBS data. These findings suggest that the merged sample is skewed toward large manufacturing firms in China.

\footnotetext{
${ }^{4}$ Note that although Customs dataset includes both imports and exports information, the NBS dataset contains firms' exporting information only.
} 
Table A3(a). Basic summary of datasets

\begin{tabular}{cccccccc}
\hline & 2000 & 2001 & 2002 & 2003 & 2004 & 2005 & 2006 \\
\hline NBS data $^{\text {a }}$ & 119,444 & 131,437 & 145,464 & 163,332 & 238,078 & 237,116 & 263,158 \\
\#\#Export & 36,908 & 40,128 & 45,040 & 50,616 & 76,607 & 74,395 & 77,723 \\
\hline Customs data $^{b}$ & 81,995 & 89,660 & 104,245 & 124,299 & 153,779 & 179,666 & 208,425 \\
\#\#Export & 62,746 & 68,487 & 78,612 & 95,688 & 120,590 & 144,030 & 171,205 \\
\#\#Import & 62,750 & 67,588 & 77,303 & 87,934 & 102,242 & 113,456 & 121,835 \\
\hline Merged data $^{c}$ & 25,712 & 29,615 & 33,918 & 39,020 & 56,937 & 57,058 & 60,999 \\
\#\#Export $^{\text {\#\#Import }}$ & 19,104 & 21,914 & 25,683 & 30,611 & 44,790 & 46,372 & 50,211 \\
Merge Ratio $^{\mathrm{d}}$ & 18,094 & 20,041 & 22,700 & 25,787 & 36,943 & 36,332 & 38,102 \\
\hline
\end{tabular}

Notes: (a) The NBS firm-level dataset includes above-scale firms in the manufacturing sectors in China; it also reports firms' export sales, but there is no information on imports; (b) The Customs dataset contains detailed product-level information of international trade (both exports and imports) at the monthly level; we therefore aggregate such information to the firm-year level in order to merge it with the NBS dataset; (c) The merge of the two dataset is mainly based on the firm name, and other firm characteristics such as telephone number, zip code and firm address; (d) The merge ratio is computed as the number of exporting firms in the merged dataset in relation to the number of total exporting firms in the NBS dataset.

Table A3(b). Firm-level production information in merged vs. full-sample NBS data by year

\begin{tabular}{lcccccccc}
\hline Variables & 2000 & 2001 & 2002 & 2003 & 2004 & 2005 & 2006 & Average \\
\hline Sales (\%) & 41.19 & 43.08 & 43.88 & 45.54 & 45.98 & 44.95 & 43.47 & 44.01 \\
Exports (\%) & 68.55 & 71.05 & 72.94 & 74.47 & 77.10 & 76.67 & 77.42 & 74.03 \\
Number of Employees (\%) & 30.31 & 33.05 & 35.15 & 37.29 & 39.14 & 39.94 & 39.90 & 36.40 \\
\hline
\end{tabular}

Notes: the value in this table represents the percentages of total sales, exports and employment of the merged data in the full-sample NBS data.

Table A3(c). Comparison of the merged data and the full-sample NBS data

\begin{tabular}{lcccccc}
\hline Variables & \multicolumn{3}{c}{ Full-sample data } & \multicolumn{3}{c}{ Merged data } \\
\hline Sales (RMB 1,000) & Mean & Min & Max & Mean & Min & Max \\
Exports (RMB 1,000) & 68717.90 & 5001 & 9993990 & 135093.9 & 5001 & 9987010 \\
Number of Employees & 17196.51 & 0 & $1.52 \mathrm{E}+08$ & 57453.14 & 0 & $1.52 \mathrm{e}+08$ \\
\hline
\end{tabular}




\section{Online Appendix 4. More information on our distance-to-frontier measure}

Table A4. Summary statistics: distance to frontier at the 2-digit industry level (2000-2006)

\begin{tabular}{|c|c|c|c|c|c|c|c|c|c|}
\hline Industry code & Industry name & 2000 & 2001 & 2002 & 2003 & 2004 & 2005 & 2006 & Growth (\%) \\
\hline 13 & Food processing industry & 16.30 & 15.57 & 14.47 & 13.23 & 11.63 & 9.82 & 8.38 & -9.50 \\
\hline 14 & Food manufacturing industry & 23.50 & 22.60 & 21.43 & 18.82 & 17.16 & 13.98 & 11.49 & -10.22 \\
\hline 15 & Beverage manufacturing industry & 26.68 & 24.06 & 24.13 & 26.34 & 22.97 & 21.21 & 17.23 & -6.25 \\
\hline 16 & Tobacco processing industry & 36.04 & 31.81 & 19.23 & 15.30 & 12.96 & 14.53 & 11.68 & -16.10 \\
\hline 17 & Textile industry & 17.65 & 16.06 & 15.95 & 14.68 & 13.50 & 11.83 & 10.43 & -7.51 \\
\hline 18 & Clothing and other fiber products manufacturing & 15.60 & 16.02 & 17.74 & 16.70 & 16.12 & 14.55 & 13.56 & -2.00 \\
\hline 19 & Leather, fur, down and down products industry & 16.76 & 14.85 & 15.16 & 14.82 & 15.96 & 14.16 & 12.59 & -4.09 \\
\hline 20 & Timber processing, bamboo, cane, palm fiber and straw products industry & 13.85 & 12.30 & 12.03 & 13.68 & 13.32 & 10.49 & 8.46 & -7.04 \\
\hline 21 & Furniture manufacturing industry & 14.61 & 14.17 & 15.05 & 15.61 & 15.47 & 14.13 & 12.34 & -2.41 \\
\hline 22 & Paper and paper products industry & 33.79 & 29.18 & 27.26 & 22.92 & 22.60 & 18.24 & 16.89 & -9.91 \\
\hline 23 & Printing and record medium reproduction industry & 17.00 & 14.02 & 13.21 & 12.49 & 11.74 & 10.93 & 9.46 & -8.37 \\
\hline 24 & Educational and sports goods industry & 28.53 & 26.00 & 30.81 & 30.28 & 31.27 & 28.94 & 25.78 & -1.45 \\
\hline 25 & Petroleum processing and coking industry & 31.43 & 24.31 & 17.21 & 18.99 & 21.36 & 32.08 & 28.44 & -1.43 \\
\hline 26 & Chemical materials and chemical products manufacturing industry & 47.48 & 34.91 & 34.33 & 27.77 & 25.88 & 25.62 & 21.72 & -11.17 \\
\hline 27 & Pharmaceutical manufacturing industry & 49.17 & 48.36 & 45.42 & 47.12 & 42.81 & 36.54 & 33.60 & -5.44 \\
\hline 28 & Manufacture of chemical fibers industry & 16.24 & 21.27 & 17.77 & 13.48 & 15.92 & 14.49 & 13.37 & -2.78 \\
\hline 29 & Rubber product industry & 24.03 & 19.71 & 16.97 & 15.33 & 16.34 & 12.81 & 10.48 & -11.85 \\
\hline 30 & Plastic products industry & 14.49 & 12.76 & 12.02 & 14.38 & 12.02 & 12.27 & 11.05 & -3.87 \\
\hline 31 & Non-metallic mineral products industry & 30.95 & 27.35 & 26.02 & 22.01 & 19.12 & 16.68 & 13.97 & -11.36 \\
\hline 32 & Ferrous metal smelting and rolling processing industry & 16.16 & 12.98 & 12.29 & 8.53 & 7.73 & 6.69 & 6.09 & -13.94 \\
\hline 33 & Non-ferrous metal smelting and rolling processing industry & 21.05 & 16.04 & 15.81 & 11.86 & 11.33 & 8.73 & 6.55 & -16.68 \\
\hline 34 & Fabricated metal products industry & 16.92 & 15.05 & 14.73 & 13.09 & 12.93 & 11.33 & 9.89 & -7.67 \\
\hline 35 & General machinery manufacturing industry & 25.73 & 22.11 & 20.33 & 16.33 & 13.92 & 12.04 & 10.55 & -12.74 \\
\hline 36 & Special equipment manufacturing industry & 36.79 & 27.96 & 25.75 & 22.43 & 18.48 & 16.95 & 13.98 & -13.82 \\
\hline 37 & Transportation equipment manufacturing industry & 24.67 & 18.92 & 17.63 & 15.18 & 13.86 & 12.87 & 10.80 & -11.80 \\
\hline 39 & Weapons and ammunition industry & 17.94 & 14.70 & 15.08 & 14.31 & 14.37 & 13.01 & 11.00 & -6.99 \\
\hline 40 & Electrical machinery and equipment manufacturing & 16.95 & 11.78 & 11.64 & 12.11 & 14.41 & 13.93 & 12.44 & -4.42 \\
\hline 41 & Electronic and communication equipment manufacturing industry & 30.42 & 22.06 & 19.74 & 18.15 & 18.29 & 15.90 & 14.00 & -11.09 \\
\hline 42 & Instrumentation and culture, office machinery manufacturing industry & 22.53 & 20.88 & 21.14 & 20.64 & 22.51 & 20.39 & 16.95 & -4.07 \\
\hline
\end{tabular}

Notes: industry code is the 2-digit Chinese Standard Industrial Classification (CSIC) code; the growth (\%) is the annual average growth rate of distance to frontier over the period 2000-06, i.e. $(\ln (2006$ distance $)-\ln (2000$ distance $)) / 7$. 
Online Appendix 5. More robustness tests

Table A5. Baseline results: import competition effects on R\&D expenditure

\begin{tabular}{|c|c|c|c|c|c|c|}
\hline \multirow{2}{*}{ Dep var: $\ln (R \& D)$} & \multicolumn{3}{|c|}{ Industry distance measure (IDF) } & \multicolumn{3}{|c|}{ Firm distance measure (FDF) } \\
\hline & (1) & $(2)$ & (3) & (4) & $(5)$ & $(6)$ \\
\hline \multirow[t]{2}{*}{ IMP } & $0.866^{* * *}$ & $0.867 * * *$ & $0.818^{* * *}$ & $1.205 * *$ & $1.206^{* *}$ & $1.224 * *$ \\
\hline & $(0.312)$ & $(0.312)$ & $(0.313)$ & $(0.549)$ & $(0.549)$ & $(0.549)$ \\
\hline \multirow[t]{2}{*}{$\mathrm{DF} \times \mathrm{IMP}$} & $-0.310 * * *$ & $-0.310 * * *$ & $-0.287 * * *$ & $-0.118 * *$ & $-0.118 * *$ & $-0.119 * *$ \\
\hline & $(0.110)$ & $(0.110)$ & $(0.111)$ & $(0.053)$ & $(0.053)$ & $(0.053)$ \\
\hline \multirow[t]{2}{*}{ DF } & $-0.018 *$ & $-0.018 *$ & $-0.023 * *$ & $0.043 * * *$ & $0.043 * * *$ & $0.043 * * *$ \\
\hline & $(0.011)$ & $(0.011)$ & $(0.011)$ & $(0.003)$ & $(0.003)$ & $(0.003)$ \\
\hline \multirow[t]{2}{*}{ Age } & -0.002 & -0.002 & -0.002 & -0.004 & -0.004 & -0.004 \\
\hline & $(0.006)$ & $(0.006)$ & $(0.006)$ & $(0.006)$ & $(0.006)$ & $(0.006)$ \\
\hline \multirow[t]{2}{*}{ Size } & $0.163 * * *$ & $0.163 * * *$ & $0.163 * * *$ & $0.190 * * *$ & $0.190 * * *$ & $0.191 * * *$ \\
\hline & $(0.004)$ & $(0.004)$ & $(0.004)$ & $(0.005)$ & $(0.005)$ & $(0.005)$ \\
\hline \multirow[t]{2}{*}{ Capital intensity } & $0.021 * * *$ & $0.021 * * *$ & $0.021 * * *$ & $0.029 * * *$ & $0.029 * * *$ & $0.029 * * *$ \\
\hline & $(0.003)$ & $(0.003)$ & $(0.003)$ & $(0.003)$ & $(0.003)$ & $(0.003)$ \\
\hline \multirow[t]{2}{*}{ Exit } & $-0.070 * * *$ & $-0.070 * * *$ & $-0.070 * * *$ & $-0.068 * * *$ & $-0.068 * * *$ & $-0.068 * * *$ \\
\hline & $(0.006)$ & $(0.006)$ & $(0.006)$ & $(0.006)$ & $(0.006)$ & $(0.006)$ \\
\hline \multirow[t]{2}{*}{ HHI } & -0.249 & -0.248 & -0.250 & -0.281 & -0.280 & -0.246 \\
\hline & $(0.201)$ & $(0.201)$ & $(0.208)$ & $(0.200)$ & $(0.200)$ & $(0.207)$ \\
\hline \multirow[t]{2}{*}{ SOE } & $-0.118 * * *$ & $-0.118 * * *$ & $-0.118 * * *$ & $-0.120 * * *$ & $-0.120 * * *$ & $-0.120 * * *$ \\
\hline & $(0.014)$ & $(0.014)$ & $(0.014)$ & $(0.014)$ & $(0.014)$ & $(0.014)$ \\
\hline \multirow[t]{2}{*}{$\mathrm{COL}$} & $-0.022 * * *$ & $-0.022 * * *$ & $-0.022 * * *$ & $-0.022 * * *$ & $-0.022 * * *$ & $-0.022 * * *$ \\
\hline & $(0.005)$ & $(0.005)$ & $(0.005)$ & $(0.005)$ & $(0.005)$ & $(0.005)$ \\
\hline \multirow[t]{2}{*}{ FIE } & -0.015 & -0.015 & -0.015 & -0.015 & -0.015 & -0.015 \\
\hline & $(0.012)$ & $(0.012)$ & $(0.012)$ & $(0.012)$ & $(0.012)$ & $(0.012)$ \\
\hline \multirow{2}{*}{ Market } & -0.035 & -0.027 & -0.035 & -0.012 & -0.005 & -0.009 \\
\hline & $(0.049)$ & $(0.049)$ & $(0.049)$ & $(0.049)$ & $(0.049)$ & $(0.049)$ \\
\hline Year fixed effects & Yes & Yes & Yes & Yes & Yes & Yes \\
\hline Firm fixed effects & Yes & Yes & Yes & Yes & Yes & Yes \\
\hline Province fixed effects & No & Yes & Yes & No & Yes & Yes \\
\hline Industry fixed effects & No & No & Yes & No & No & Yes \\
\hline Max of DF & 5.957 & 5.957 & 5.957 & 14.090 & 14.090 & 14.090 \\
\hline Min of DF & 1.041 & 1.041 & 1.041 & 7.015 & 7.015 & 7.015 \\
\hline Mean of DF & 2.803 & 2.803 & 2.803 & 10.100 & 10.100 & 10.100 \\
\hline Adj-R ${ }^{2}$ & 0.009 & 0.009 & 0.009 & 0.009 & 0.009 & 0.009 \\
\hline Observations & 889113 & 889113 & 889113 & 889113 & 889113 & 889113 \\
\hline
\end{tabular}

Notes: standard errors are reported in parentheses, which are clustered at the firm level; *** $\mathrm{p}<0.01, * * \mathrm{p}<0.05, * \mathrm{p}<0.1$. 
Table A6. Correlation between import penetration and FDI

Panel A: 2000

\begin{tabular}{|c|c|c|c|c|c|}
\hline & IMP & Ordinary IMP & Processing IMP & FIE & FDI \\
\hline IMP & 1.0000 & & & & \\
\hline Ordinary IMP & $0.8078 *$ & 1.0000 & & & \\
\hline Processing IMP & $0.5119^{*}$ & $0.2522 *$ & 1.0000 & & \\
\hline FIE & -0.0011 & -0.0431 & $0.1738^{*}$ & 1.0000 & \\
\hline FDI & $0.1919 *$ & 0.0990 & $0.3171 *$ & $0.7689 *$ & 1.0000 \\
\hline
\end{tabular}

Panel B: 2003

\begin{tabular}{l|ccccc}
\hline & IMP & Ordinary IMP & Processing IMP & FIE & FDI \\
\hline IMP & 1.0000 & & & & \\
Ordinary IMP & $0.8129^{*}$ & 1.0000 & & & \\
Processing IMP & $0.4628^{*}$ & $0.1849^{*}$ & 1.0000 & & \\
FIE & 0.0066 & -0.0829 & $0.2125^{*}$ & 1.0000 & 1.0000 \\
FDI & $0.1116^{*}$ & 0.0278 & $0.2228^{*}$ & $0.7896^{*}$ & 1 \\
\hline
\end{tabular}

Panel C: 2006

\begin{tabular}{|c|c|c|c|c|c|}
\hline & IMP & Ordinary IMP & Processing IMP & FIE & FDI \\
\hline IMP & 1.0000 & & & & \\
\hline Ordinary IMP & $0.8078^{*}$ & 1.0000 & & & \\
\hline Processing IMP & $0.3571 *$ & $0.2031 *$ & 1.0000 & & \\
\hline FIE & 0.0966 & $-0.1216^{*}$ & $0.1717^{*}$ & 1.0000 & \\
\hline FDI & 0.0966 & 0.0105 & $0.1961 *$ & $0.7909 *$ & 1.0000 \\
\hline
\end{tabular}

Notes: IMP is the import penetration ratio; Ordinary IMP is the ordinary-trade import penetration ratio; Processing IMP is the processing-trade import penetration ratio; FIE is the first proxy for FDI, measured as the firms' foreign share of capital as in Javorcik (2004); and FDI is the second proxy for FDI, measured as the ratio of foreign investment to total assets as in Fu and Gong (2011). *** $\mathrm{p}<0.01, * * \mathrm{p}<0.05, * \mathrm{p}<0.1$. 
Table A7. Import competition effects on TFP growth using system GMM estimation

\begin{tabular}{|c|c|c|c|c|c|c|}
\hline \multirow{2}{*}{ Dep var: TFP growth } & \multicolumn{3}{|c|}{ Industry distance measure (IDF) } & \multicolumn{3}{|c|}{ Firm distance measure (FDF) } \\
\hline & (1) & (2) & (3) & (4) & (5) & (6) \\
\hline IMP & $\begin{array}{c}0.423 * * * \\
(0.117)\end{array}$ & $\begin{array}{c}0.405^{* * *} \\
(0.116)\end{array}$ & $\begin{array}{c}0.403 * * * \\
(0.112)\end{array}$ & $\begin{array}{c}0.788^{* * *} \\
(0.249)\end{array}$ & $\begin{array}{c}0.877 * * * \\
(0.259)\end{array}$ & $\begin{array}{c}0.872 * * * \\
(0.255)\end{array}$ \\
\hline $\mathrm{DF} \times \mathrm{IMP}$ & $\begin{array}{c}-0.545^{* * *} \\
(0.205)\end{array}$ & $\begin{array}{c}-0.539 * * * \\
(0.193)\end{array}$ & $\begin{array}{c}-0.538^{* * *} \\
(0.195)\end{array}$ & $\begin{array}{c}-0.311 * * * \\
(0.103)\end{array}$ & $\begin{array}{c}-0.310^{* *} \\
(0.101)\end{array}$ & $\begin{array}{c}-0.309^{* *} \\
(0.099)\end{array}$ \\
\hline DF & $\begin{array}{c}0.022 * * * \\
(0.007)\end{array}$ & $\begin{array}{c}0.019 * * * \\
(0.007)\end{array}$ & $\begin{array}{c}0.021 * * * \\
(0.007)\end{array}$ & $\begin{array}{c}0.004 * * * \\
(0.000)\end{array}$ & $\begin{array}{c}0.007 * * * \\
(0.000)\end{array}$ & $\begin{array}{c}0.007 * * * \\
(0.000)\end{array}$ \\
\hline Age & $\begin{array}{c}-0.026^{* * *} \\
(0.000)\end{array}$ & $\begin{array}{c}-0.021 * * * \\
(0.000)\end{array}$ & $\begin{array}{c}-0.015 * * * \\
(0.000)\end{array}$ & $\begin{array}{c}-0.028 * * * \\
(0.000)\end{array}$ & $\begin{array}{c}-0.023 * * * \\
(0.000)\end{array}$ & $\begin{array}{c}-0.021 * * * \\
(0.000)\end{array}$ \\
\hline Size & $\begin{array}{c}0.014 * * * \\
(0.000)\end{array}$ & $\begin{array}{c}0.013 * * * \\
(0.000)\end{array}$ & $\begin{array}{c}0.011 * * * \\
(0.000)\end{array}$ & $\begin{array}{c}0.012 * * * \\
(0.000)\end{array}$ & $\begin{array}{c}0.010 * * * \\
(0.000)\end{array}$ & $\begin{array}{c}0.009 * * * \\
(0.000)\end{array}$ \\
\hline Capital intensity & $\begin{array}{c}0.015^{* * *} * \\
(0.001)\end{array}$ & $\begin{array}{c}0.014 * * * \\
(0.000)\end{array}$ & $\begin{array}{c}0.011 * * * \\
(0.000)\end{array}$ & $\begin{array}{c}0.016^{* * * *} \\
(0.001)\end{array}$ & $\begin{array}{c}0.012 * * * \\
(0.000)\end{array}$ & $\begin{array}{c}0.010 * * * \\
(0.000)\end{array}$ \\
\hline Exit & $\begin{array}{c}-0.012 * * * \\
(0.001)\end{array}$ & $\begin{array}{c}-0.005 * * * \\
(0.001)\end{array}$ & $\begin{array}{c}-0.004 * * * \\
(0.001)\end{array}$ & $\begin{array}{c}-0.019 * * * \\
(0.000)\end{array}$ & $\begin{array}{c}-0.010 * * * \\
(0.001)\end{array}$ & $\begin{array}{c}-0.003 * * * \\
(0.001)\end{array}$ \\
\hline HHI & $\begin{array}{c}-0.023 * * * \\
(0.004)\end{array}$ & $\begin{array}{c}-0.017 * * * \\
(0.001)\end{array}$ & $\begin{array}{c}-0.016^{* * *} * \\
(0.001)\end{array}$ & $\begin{array}{c}-0.023 * * * \\
(0.004)\end{array}$ & $\begin{array}{c}-0.017 * * * \\
(0.001)\end{array}$ & $\begin{array}{c}-0.016 * * * \\
(0.001)\end{array}$ \\
\hline SOE & $\begin{array}{c}-0.031 * * * \\
(0.003)\end{array}$ & $\begin{array}{c}-0.030 * * * \\
(0.001)\end{array}$ & $\begin{array}{c}-0.029 * * * \\
(0.001)\end{array}$ & $\begin{array}{c}-0.030^{* * *} \\
(0.003)\end{array}$ & $\begin{array}{c}-0.034 * * * \\
(0.001)\end{array}$ & $\begin{array}{c}-0.035 * * * \\
(0.001)\end{array}$ \\
\hline $\mathrm{COL}$ & $\begin{array}{l}-0.003 \\
(0.002)\end{array}$ & $\begin{array}{c}-0.005^{* *} \\
(0.002)\end{array}$ & $\begin{array}{l}-0.004 \\
(0.003)\end{array}$ & $\begin{array}{l}-0.002 \\
(0.002)\end{array}$ & $\begin{array}{l}-0.004^{*} \\
(0.002)\end{array}$ & $\begin{array}{l}-0.004 \\
(0.003)\end{array}$ \\
\hline FIE & $\begin{array}{c}0.018^{* * *} \\
(0.003)\end{array}$ & $\begin{array}{c}0.005 * * * \\
(0.001)\end{array}$ & $\begin{array}{c}0.005^{* * *} * \\
(0.001)\end{array}$ & $\begin{array}{c}0.018 * * * \\
(0.003)\end{array}$ & $\begin{array}{c}0.006^{* * *} \\
(0.001)\end{array}$ & $\begin{array}{c}0.006^{* * *} \\
(0.001)\end{array}$ \\
\hline Market & $\begin{array}{c}0.006^{* * *} \\
(0.001)\end{array}$ & $\begin{array}{c}0.005^{* * *} \\
(0.001)\end{array}$ & $\begin{array}{c}0.005^{* * *} \\
(0.001)\end{array}$ & $\begin{array}{c}0.006^{* * *} \\
(0.001)\end{array}$ & $\begin{array}{c}0.005^{* * *} \\
(0.001)\end{array}$ & $\begin{array}{c}0.005^{* * *} \\
(0.001) \\
\end{array}$ \\
\hline Year fixed effects & Yes & Yes & Yes & Yes & Yes & Yes \\
\hline Firm fixed effects & Yes & Yes & Yes & Yes & Yes & Yes \\
\hline Province fixed effects & No & Yes & Yes & No & Yes & Yes \\
\hline Industry fixed effects & No & No & Yes & No & No & Yes \\
\hline Max of DF & 5.957 & 5.957 & 5.957 & 14.090 & 14.090 & 14.090 \\
\hline Min of DF & 1.041 & 1.041 & 1.041 & 7.015 & 7.015 & 7.015 \\
\hline Mean of DF & 2.803 & 2.803 & 2.803 & 10.100 & 10.100 & 10.100 \\
\hline AR(2) p-value & 0.21 & 0.29 & 0.22 & 0.44 & 0.31 & 0.27 \\
\hline Hansen J p-value & 0.17 & 0.12 & 0.13 & 0.13 & 0.14 & 0.22 \\
\hline Observation & 945387 & 945387 & 945387 & 945387 & 945387 & 945387 \\
\hline
\end{tabular}

Notes: standard errors are reported in parentheses, which are clustered at the firm level; ${ }^{* *} \mathrm{p}<0.01,{ }^{* *} \mathrm{p}<0.05,{ }^{*} \mathrm{p}<0.1$ 
Table A8. Import competition effects on long-term TFP growth (3-year effects)

\begin{tabular}{|c|c|c|c|c|c|c|}
\hline \multirow{2}{*}{ Dep var: TFP growth } & \multicolumn{3}{|c|}{ Industry distance measure (IDF) } & \multicolumn{3}{|c|}{ Firm distance measure (FDF) } \\
\hline & (1) & (2) & (3) & (4) & $(5)$ & (6) \\
\hline \multirow[t]{2}{*}{ IMP } & $0.105 * *$ & $0.105 * *$ & $0.032 * *$ & $0.172 * * *$ & $0.172 * * *$ & $0.227 * * *$ \\
\hline & $(0.050)$ & $(0.050)$ & $(0.015)$ & $(0.063)$ & $(0.063)$ & $(0.056)$ \\
\hline \multirow[t]{2}{*}{$\mathrm{DF} \times \mathrm{IMP}$} & $-0.056 * * *$ & $-0.056 * * *$ & $-0.009 * * *$ & $-0.023 * * *$ & $-0.023 * * *$ & $-0.023 * * *$ \\
\hline & $(0.018)$ & $(0.018)$ & $(0.002)$ & $(0.006)$ & $(0.006)$ & $(0.006)$ \\
\hline \multirow[t]{2}{*}{ DF } & $-0.011 * * *$ & $-0.011 * * *$ & $-0.004 * * *$ & $0.058 * * *$ & $0.058 * * *$ & $0.057 * * *$ \\
\hline & $(0.002)$ & $(0.002)$ & $(0.002)$ & $(0.001)$ & $(0.001)$ & $(0.001)$ \\
\hline \multirow[t]{2}{*}{ Age } & $-0.003 * * *$ & $-0.003 * * *$ & $-0.003 * * *$ & $-0.004 * * *$ & $-0.004 * * *$ & $-0.004 * * *$ \\
\hline & $(0.001)$ & $(0.001)$ & $(0.001)$ & $(0.001)$ & $(0.001)$ & $(0.001)$ \\
\hline \multirow[t]{2}{*}{ Size } & $0.053 * * *$ & $0.053 * * *$ & $0.052 * * *$ & $0.091 * * *$ & $0.091 * * *$ & $0.090 * * *$ \\
\hline & $(0.001)$ & $(0.001)$ & $(0.001)$ & $(0.001)$ & $(0.001)$ & $(0.001)$ \\
\hline \multirow{2}{*}{ Capital intensity } & $0.025 * * *$ & $0.025 * * *$ & $0.025 * * *$ & $0.038 * * *$ & $0.038 * * *$ & $0.037 * * *$ \\
\hline & $(0.001)$ & $(0.001)$ & $(0.001)$ & $(0.001)$ & $(0.001)$ & $(0.001)$ \\
\hline \multirow[t]{2}{*}{ Exit } & $-0.002 *$ & $-0.002 *$ & $-0.003 * *$ & 0.000 & 0.000 & -0.000 \\
\hline & $(0.001)$ & $(0.001)$ & $(0.001)$ & $(0.001)$ & $(0.001)$ & $(0.001)$ \\
\hline \multirow[t]{2}{*}{ HHI } & $-0.109 * * *$ & $-0.109 * * *$ & 0.005 & $-0.141 * * *$ & $-0.140 * * *$ & -0.016 \\
\hline & $(0.040)$ & $(0.040)$ & $(0.029)$ & $(0.039)$ & $(0.039)$ & $(0.028)$ \\
\hline \multirow[t]{2}{*}{ SOE } & -0.001 & -0.001 & 0.000 & $-0.003 *$ & -0.003 & -0.002 \\
\hline & $(0.002)$ & $(0.002)$ & $(0.002)$ & $(0.002)$ & $(0.002)$ & $(0.001)$ \\
\hline \multirow[t]{2}{*}{$\mathrm{COL}$} & 0.000 & 0.000 & -0.000 & 0.000 & 0.000 & -0.000 \\
\hline & $(0.001)$ & $(0.001)$ & $(0.001)$ & $(0.001)$ & $(0.001)$ & $(0.001)$ \\
\hline \multirow[t]{2}{*}{ FIE } & -0.001 & -0.001 & -0.001 & -0.001 & -0.001 & -0.001 \\
\hline & $(0.002)$ & $(0.002)$ & $(0.001)$ & $(0.001)$ & $(0.001)$ & $(0.001)$ \\
\hline \multirow[t]{2}{*}{ Market } & $0.056^{* * *}$ & $0.055 * * *$ & $0.049 * * *$ & $0.078 * * *$ & $0.078 * * *$ & $0.069 * * *$ \\
\hline & $(0.009)$ & $(0.009)$ & $(0.009)$ & $(0.009)$ & $(0.009)$ & $(0.008)$ \\
\hline Year fixed effects & Yes & Yes & Yes & Yes & Yes & Yes \\
\hline Firm fixed effects & Yes & Yes & Yes & Yes & Yes & Yes \\
\hline Province fixed effects & No & Yes & Yes & Yes & Yes & Yes \\
\hline Industry fixed effects & No & No & Yes & No & No & Yes \\
\hline Max of DF & 5.957 & 5.957 & 5.957 & 14.090 & 14.090 & 14.090 \\
\hline Min of DF & 1.041 & 1.041 & 1.041 & 7.015 & 7.015 & 7.015 \\
\hline Mean of DF & 2.803 & 2.803 & 2.803 & 10.100 & 10.100 & 10.100 \\
\hline Adj-R ${ }^{2}$ & 0.070 & 0.070 & 0.173 & 0.139 & 0.139 & 0.240 \\
\hline Observations & 358547 & 358547 & 358547 & 358547 & 358547 & 358547 \\
\hline
\end{tabular}

Notes: standard errors are reported in parentheses, which are clustered at the firm level; *** $\mathrm{p}<0.01,{ }^{* *} \mathrm{p}<0.05,{ }^{*} \mathrm{p}<0.1$ 